\title{
Rapid Molecular Detection Methods for Arboviruses of Livestock of Importance to Northern Europe
}

\author{
Nicholas Johnson, ${ }^{1}$ Katja Voller, ${ }^{1}$ L. Paul Phipps, ${ }^{1}$ Karen Mansfield, ${ }^{1}$ and Anthony R. Fooks ${ }^{1,2}$ \\ ${ }^{1}$ Animal Health and Veterinary Laboratories Agency, Woodham Lane, Addlestone, Surrey KT15 3NB, UK \\ ${ }^{2}$ National Centre for Zoonoses Research, University of Liverpool, Leahurst Chester High Road, Neston CH64 7TE, UK
}

Correspondence should be addressed to Nicholas Johnson, nick.johnson@ahvla.gsi.gov.uk

Received 28 July 2011; Revised 14 October 2011; Accepted 25 October 2011

Academic Editor: Roy A. Hall

Copyright (C) 2012 Nicholas Johnson et al. This is an open access article distributed under the Creative Commons Attribution License, which permits unrestricted use, distribution, and reproduction in any medium, provided the original work is properly cited.

\begin{abstract}
Arthropod-borne viruses (arboviruses) have been responsible for some of the most explosive epidemics of emerging infectious diseases over the past decade. Their impact on both human and livestock populations has been dramatic. The early detection either through surveillance or diagnosis of virus will be a critical feature in responding and resolving the emergence of such epidemics in the future. Although some of the most important emerging arboviruses are human pathogens, this paper aims to highlight those diseases that primarily affect livestock, although many are zoonotic and some occasionally cause human mortality. This paper also highlights the molecular detection methods specific to each virus and identifies those emerging diseases for which a rapid detection methods are not yet developed.
\end{abstract}

\section{Introduction}

In 1983, Odend' Hal [1] published a short book listing the worldwide distribution of animal viruses. It reported the classification as well as host, historical movements, and diagnostic techniques available. Of the 110 viruses cited, 35 were arboviruses, those viruses that are transmitted primarily by an arthropod vector. This first attempt at mapping animal viruses provides a useful baseline for reviewing the current state of arboviruses of livestock. Arboviruses are mainly classified to the virus families Bunyaviridae, Togaviridae, Reoviridae, and Flaviviridae [2]. The majority of these virus families have a ribonucleic acid genome, with the clear exception of the Asfarviridae to which African swine fever virus belongs (Table 1 ).

In Table 2 an updated list of arthropod-borne virus pathogens of humans, livestock, and wildlife is provided. During recent years several pathogenic arboviruses have apparently dispersed to new locations. The most well-known cases have been the movement of West Nile virus from the Old world to the New World [3] and the introduction of bluetongue virus into northern Europe [4]. This has prompted a wide range of authors to review the potential viruses that could emerge in the UK and Europe and assess the risk of such emergence events in the future [5-9].

The cooler climate experienced in northern latitudes (above $50^{\circ}$ ) means that there are fewer species and less diversity among particular arthropod species and the viruses they harbour than found in subtropical and tropical regions. Currently, there are few arthropod-borne diseases of livestock in Europe and as a result, livestock in the UK and many areas of northern Europe may be highly susceptible to many arthropod-borne viruses listed in Table 2 . The health impact of an emergence of one could likely be severe. An exception to this is the presence of louping ill virus, which is considered to be the only arbovirus of veterinary importance that is endemic within the UK. The virus has been present for hundreds of years and is restricted to moorland locations, particularly in Devon, Cumbria, Wales, and Scotland [10]. This tick-borne virus causes fatal encephalitic disease in sheep, although it has been reported in a range of other species. A number of reports have suggested that West Nile virus and two other mosquito-borne viruses had been introduced into the UK, although cases of disease in horses have not been reported [11]. This is in clear contrast to the situation in Italy where WNV has repeatedly emerged 
TABLE 1: Details of selected arbovirus families.

\begin{tabular}{lcccc}
\hline Virus family & Enveloped & Genome $($ sense) & Segmentation (number) & Example virus \\
\hline Bunyaviridae & Yes & RNA SS $^{1}(-)$ & 3 & Rift Valley fever \\
Flaviviridae & Yes & RNA SS $(+)$ & Nonsegmented & Dengue virus \\
Reoviridae & No & RNA DS & Bluetongue virus \\
Rhabdoviridae & Yes & RNA SS $(-)$ & Nonsegmented & Vesicular stomatitis virus \\
Togaviridae & Yes & RNA SS $(+)$ & Nonsegmented & Chikungunya virus \\
Asfarviridae & Yes & DNA DS & Nonsegmented & African swine fever virus \\
Orthomyxoviridae & Yes & RNA SS $(-)$ & 8 & Thogoto virus \\
\hline
\end{tabular}

${ }^{1}$ Single-stranded.

${ }^{2}$ Double-stranded.

to cause neurologic disease in horses from the Tuscany Region [12]. Recurring outbreaks of disease have occurred in both livestock and humans suggesting the permanent establishment of this virus in the mosquito population [13]. This has made assessment of future climate change trends essential to understanding the impact on both the ecology of the UK and risk of vector-borne disease introduction and establishment [9]. Such changes might enhance the establishment of invasive arthropod species such as the Asian tiger mosquito (Aedes albopictus) that in turn could directly import an exotic virus. It could also boost the population of indigenous vectors that could in turn increase the numbers of biting events, enhancing the likelihood of virus transmission. Furthermore, increases in temperatures can shorten the extrinsic incubation period, the time between the vector taking a blood meal and becoming infectious to a new host, thus enhancing virus persistence in a new area.

A wide range of routes would enable arthropod-borne viruses to translocate into a disease-free area. These can be divided into those that are part of the normal ecology and are influenced by the environment and climate that are presumably occurring all the time. Avian migration is an example of this pathway. Avian species are known to harbour many pathogens [14] and certain viruses such as avian influenza and Newcastle disease virus are transmitted around the globe through bird migration. For arthropod-borne viruses, virus movement can occur via transportation of the vector [15] or through infection of the host, particularly a viraemic animal that is subsequently fed on by an arthropod in a disease-free destination. The range of Crimean-Congo haemorrhagic fever appears to be increasing slowly in south-east Europe associated with spread by its tick vector (Hyalomma spp.). Bluetongue virus transmission into the UK is believed to have resulted from direct introduction of its midge vector (Culicoides spp.) assisted by wind movements in 2007 [16]. It is likely that movements by these routes, if they happen, are occurring continuously and cannot realistically be controlled. Therefore, effort needs to be directed towards reducing the impact of introduction. The alternative to natural introduction is often mediated by the actions of man. Again, this could occur through passive introduction of the vector through the movement of humans, livestock, or trade goods between endemic and disease-free areas or by the movement of infected livestock between countries.
Theoretically, these mechanisms of entry can be regulated and effort should be directed to prevention programs.

A key aspect in preparing for the emergence of arthropod-borne diseases is the establishment of tests capable of detecting them. Development of such tests needs to address a number of fundamental issues. These include key features such as sensitivity of the assay and its specificity for the target virus. The assay must also be validated to provide assurance of its reliability, or at least give an indication of what might be missed. The assay under development needs to compete with existing technologies in terms of cost and speed to deliver desirable benefits to encourage adoption. The application of a particular test needs to be considered. Some tests may be applied to surveillance for virus, in which case the test needs to be amenable to cost-effective delivery of high volumes of samples. This in turn can complement serosurveys for particular viruses or be applied to sampling arthropod vectors in order to provide early warning of potential disease incursion.

For some technologies, the cost of individual tests is prohibitive for application to large numbers of samples or in resource-poor areas such as Africa. In each of these areas, molecular detection techniques have been very competitive as evidenced by the numerous tests developed in recent decades. Many of the assays reported in this paper provide a result considerably faster than more traditional detection methods such as virus isolation and plaque-reduction neutralization tests. Genetic variability of viruses is an inherent weakness in the use of molecular detection techniques with primer-mismatch being a constant problem. This has to some extent been overcome by the wealth of sequence data now available on many of the viruses that affect livestock.

Here we provide an overview of those arthropod-borne viruses that cause clinical disease in livestock and lead to economic losses. It will not consider important arboviruses that cause significant human disease with no livestock involvement such as yellow fever, dengue, Toscana virus, and chikungunya virus. Background information on the disease caused by particular viruses is described, the main arthropod vector and the reported current geographical distribution is provided for the viruses selected. This is followed by a brief review of reported rapid molecular tests that detect specific viruses or those tests that detect virus groups that contain numbers of animal pathogens. 
TABle 2: Pathogenic arboviruses (viruses in bold are dealt with in greater detail later in the paper).

\begin{tabular}{|c|c|c|c|c|c|c|}
\hline Virus & $\begin{array}{l}\text { Classification: } \\
\text { family genus }\end{array}$ & Vector & Animals affected & $\begin{array}{c}\text { Disease } \\
\left(\mathrm{SFI}^{1}, \mathrm{HF}^{2}, \mathrm{E}^{3}\right)\end{array}$ & Endemic presence & $\begin{array}{l}\text { OIE* }^{*} \\
\text { listed }\end{array}$ \\
\hline $\begin{array}{l}\text { African horse sickness } \\
\text { virus }\end{array}$ & $\begin{array}{c}\text { Asfarviridae } \\
\text { Asfivirus }\end{array}$ & Midge (Culicoides spp.) & Horses & SFI/HF & Africa & Yes \\
\hline $\begin{array}{l}\text { African swine fever } \\
\text { virus }\end{array}$ & $\begin{array}{l}\text { Reoviridae } \\
\text { Orbivirus }\end{array}$ & Ticks (Argasid spp.) & Pigs & HF & Africa & Yes \\
\hline Akabane virus & $\begin{array}{l}\text { Bunyaviridae } \\
\text { Orthobunyavirus }\end{array}$ & $\begin{array}{l}\text { Mosquito (Aedes spp.) } \\
\text { and midges }\end{array}$ & $\begin{array}{l}\text { Cattle, sheep, } \\
\text { horse, }\end{array}$ & $\begin{array}{c}\text { Congenital } \\
\text { abnormalities }\end{array}$ & $\begin{array}{l}\text { East Asia, Turkey, } \\
\text { South Africa }\end{array}$ & No \\
\hline Bluetongue virus & $\begin{array}{l}\text { Reoviridae } \\
\text { Orbivirus }\end{array}$ & Midge (Culicoides spp.) & Cattle, sheep, goat & HF & $\begin{array}{c}\text { Americas, Africa, } \\
\text { Asia }\end{array}$ & Yes \\
\hline $\begin{array}{l}\text { Bovine ephemeral fever } \\
\text { virus }\end{array}$ & $\begin{array}{l}\text { Rhabdoviridae } \\
\text { Ephemerovirus }\end{array}$ & Midge/mosquito & Cattle & SFI/respiratory & $\begin{array}{l}\text { Africa, Asia, } \\
\text { Australia }\end{array}$ & No \\
\hline $\begin{array}{l}\text { California encephalitis } \\
\text { virus }\end{array}$ & $\begin{array}{l}\text { Bunyaviridae } \\
\text { Orthobunyavirus }\end{array}$ & Mosquito & $\begin{array}{l}\text { Humans, small } \\
\text { mammals }\end{array}$ & $\mathrm{E}$ & Americas & No \\
\hline Chikungunya virus & $\begin{array}{l}\text { Togaviridae } \\
\text { Alphavirus }\end{array}$ & Mosquito (Aedes spp.) & Humans & SFI & Africa, Asia, Europe & No \\
\hline $\begin{array}{l}\text { Colorado tick fever } \\
\text { virus }\end{array}$ & $\begin{array}{l}\text { Reoviridae } \\
\text { Coltivirus }\end{array}$ & $\begin{array}{l}\text { Tick (Dermocentor } \\
\text { andersonii) }\end{array}$ & $\begin{array}{l}\text { Humans, small } \\
\text { mammals }\end{array}$ & SFI & North America & No \\
\hline $\begin{array}{l}\text { Crimean-Congo } \\
\text { haemorrhagic fever } \\
\text { virus }\end{array}$ & $\begin{array}{l}\text { Bunyaviridae } \\
\text { Nairovirus }\end{array}$ & Ticks (Hyalomma spp.) & Humans & SFI/HF & Africa, Asia, Europe & No \\
\hline Dengue virus & $\begin{array}{l}\text { Flaviviridae } \\
\text { Flavivirus }\end{array}$ & Mosquitoes (Aedes spp.) & Humans & $\mathrm{SFI} / \mathrm{HF}$ & $\begin{array}{c}\text { Africa, Asia, } \\
\text { Americas, Europe }\end{array}$ & No \\
\hline Dugbe virus & $\begin{array}{l}\text { Bunyaviridae } \\
\text { Nairovirus }\end{array}$ & Ticks & Humans, cattle & SFI & Africa & No \\
\hline $\begin{array}{l}\text { Eastern equine } \\
\text { encephalitis virus }\end{array}$ & $\begin{array}{l}\text { Togaviridae } \\
\text { Alphavirus }\end{array}$ & $\begin{array}{l}\text { Mosquitoes (Culex } \\
\text { spp.) }\end{array}$ & Humans, equine & $\mathrm{E}$ & Americas & Yes \\
\hline $\begin{array}{l}\text { Epizootic } \\
\text { haemorrhagic disease } \\
\text { virus }\end{array}$ & $\begin{array}{c}\text { Reoviridae } \\
\text { Orbivirus }\end{array}$ & Midge (Culicoides spp.) & Cattle, deer & HF & $\begin{array}{c}\text { Americas, Africa, } \\
\text { Asia }\end{array}$ & Yes \\
\hline $\begin{array}{l}\text { Equine encephalosis } \\
\text { virus }\end{array}$ & $\begin{array}{l}\text { Reoviridae } \\
\text { Orbivirus }\end{array}$ & Midge (Culicoides spp.) & Equine & $\mathrm{E}$ & $\begin{array}{c}\text { Southern Africa, } \\
\text { Israel }\end{array}$ & No \\
\hline Getah virus & $\begin{array}{l}\text { Togaviridae, } \\
\text { Alphavirus }\end{array}$ & Mosquito (Culex spp.) & Equine & $\mathrm{SFI} / \mathrm{E}$ & Asia & No \\
\hline Inkoo virus & $\begin{array}{l}\text { Bunyaviridae } \\
\text { Orthobunyavirus }\end{array}$ & Mosquito (Aedes spp.) & Cattle & SFI & Finland & No \\
\hline $\begin{array}{l}\text { Japanese encephalitis } \\
\text { virus }\end{array}$ & $\begin{array}{l}\text { Flaviviridae } \\
\text { Flavivirus }\end{array}$ & Mosquito (Culex spp.) & $\begin{array}{l}\text { Humans, pigs, } \\
\text { horses }\end{array}$ & E/abortion & Asia & Yes \\
\hline Kemerovo virus & $\begin{array}{l}\text { Reoviridae } \\
\text { Orbivirus }\end{array}$ & Tick (Ixodes spp.) & $\begin{array}{l}\text { Humans, rodents, } \\
\text { birds }\end{array}$ & SFI & Asia & No \\
\hline Kyasanur Forest virus & $\begin{array}{l}\text { Flaviviridae } \\
\text { Flavivirus }\end{array}$ & $\begin{array}{c}\text { Ticks (Haemaphysalis } \\
\text { spp.) }\end{array}$ & $\begin{array}{l}\text { Humans, small } \\
\text { mammals }\end{array}$ & $\mathrm{E}$ & India & No \\
\hline La Crosse virus & $\begin{array}{l}\text { Bunyaviridae } \\
\text { Orthobunyavirus }\end{array}$ & Mosquito (Aedes spp.) & $\begin{array}{l}\text { Humans, Small } \\
\text { mammals }\end{array}$ & $\mathrm{E}$ & North America & No \\
\hline Louping ill virus & $\begin{array}{l}\text { Flaviviridae } \\
\text { Flavivirus }\end{array}$ & Ticks (Ixodes ricinus) & Sheep, cattle & $\mathrm{E}$ & British Isles & No \\
\hline $\begin{array}{l}\text { Murray Valley } \\
\text { encephalitis virus }\end{array}$ & $\begin{array}{l}\text { Flaviviridae } \\
\text { Flavivirus }\end{array}$ & $\begin{array}{l}\text { Mosquito (Culex } \\
\text { annulirostris) }\end{array}$ & $\begin{array}{l}\text { Humans, horse, } \\
\text { cattle }\end{array}$ & $\mathrm{E}$ & Australia, Indonesia & No \\
\hline $\begin{array}{l}\text { Nairobi sheep disease } \\
\text { virus }\end{array}$ & $\begin{array}{l}\text { Bunyaviridae } \\
\text { Nairovirus }\end{array}$ & $\begin{array}{l}\text { Tick (Ripicephalus } \\
\text { appendiculatus) }\end{array}$ & Sheep, goats & $\mathrm{HF} /$ gastroenteritis & East Africa & Yes \\
\hline $\begin{array}{l}\text { Omsk Haemorrhagic } \\
\text { fever virus }\end{array}$ & $\begin{array}{l}\text { Flaviviridae } \\
\text { Flavivirus }\end{array}$ & $\begin{array}{l}\text { Tick (Dermacentor } \\
\text { reticulatus) }\end{array}$ & Humans & $\mathrm{HF}$ & Asia & No \\
\hline Palyam virus & $\begin{array}{l}\text { Reoviridae } \\
\text { Orbivirus }\end{array}$ & Mosquitoes, midges & Cattle & Abortion & $\begin{array}{l}\text { Africa, Asia and } \\
\text { Australia }\end{array}$ & No \\
\hline $\begin{array}{l}\text { Peruvian horse sickness } \\
\text { virus }\end{array}$ & $\begin{array}{l}\text { Reoviridae } \\
\text { Orbivirus }\end{array}$ & Mosquitoes & Horses & $\mathrm{E}$ & South America & No \\
\hline Powassan virus & $\begin{array}{l}\text { Flaviviridae } \\
\text { Flavivirus }\end{array}$ & $\begin{array}{c}\text { Mosquito } \\
\text { (Aedes/Anopheles spp.) }\end{array}$ & $\begin{array}{l}\text { Small/medium } \\
\text { sized mammals }\end{array}$ & & $\begin{array}{c}\text { North America, } \\
\text { Russia }\end{array}$ & No \\
\hline
\end{tabular}


TABle 2: Continued.

\begin{tabular}{|c|c|c|c|c|c|c|}
\hline Virus & $\begin{array}{l}\text { Classification: } \\
\text { family genus }\end{array}$ & Vector & Animals affected & $\begin{array}{c}\text { Disease } \\
\left(\mathrm{SFI}^{1}, \mathrm{HF}^{2}, \mathrm{E}^{3}\right) \\
\end{array}$ & Endemic presence & $\begin{array}{l}\text { OIE* }^{*} \\
\text { listed } \\
\end{array}$ \\
\hline Rift Valley fever virus & $\begin{array}{l}\text { Bunyaviridae } \\
\text { Phlebovirus }\end{array}$ & Mosquito (Aedes spp.) & $\begin{array}{l}\text { Humans, sheep, } \\
\text { goats, camels }\end{array}$ & SFI/HF/abortion & Africa & Yes \\
\hline $\begin{array}{l}\text { Russian spring-summer } \\
\text { encephalitis virus }\end{array}$ & $\begin{array}{l}\text { Flaviviridae } \\
\text { Flavivirus }\end{array}$ & Tick (Ixodes persulcatus) & $\begin{array}{l}\text { Humans, cattle, } \\
\text { goats }\end{array}$ & $\mathrm{E}$ & Eurasia & No \\
\hline Sandfly fever virus & $\begin{array}{l}\text { Bunyaviridae } \\
\text { Phlebovirus }\end{array}$ & $\begin{array}{c}\text { Sandfly (Phlebotomus } \\
\text { perniciosus) }\end{array}$ & Humans & SFI & Europe & No \\
\hline Sindbis virus & $\begin{array}{l}\text { Togaviridae, } \\
\text { Alphavirus }\end{array}$ & Mosquito & Wildlife, avian & SFI & Africa, Europe, Asia & No \\
\hline $\begin{array}{l}\text { St. Louis encephalitis } \\
\text { virus }\end{array}$ & $\begin{array}{l}\text { Flaviviridae } \\
\text { Flavivirus }\end{array}$ & Mosquito (Culex spp.) & Humans, avian & $\mathrm{E}$ & Americas & No \\
\hline Semliki Forest virus & $\begin{array}{l}\text { Togaviridae } \\
\text { Alphavirus }\end{array}$ & Mosquito (Aedes spp.) & Equine & $\mathrm{E}$ & Africa & No \\
\hline Tahyna virus & $\begin{array}{c}\text { Bunyaviridea } \\
\text { Orthobunyavirus }\end{array}$ & Mosquito (Aedes spp.) & Humans, pigs & SFI & Africa, Europe & No \\
\hline $\begin{array}{l}\text { Tick-borne encephalitis } \\
\text { virus }\end{array}$ & $\begin{array}{l}\text { Flaviviridae } \\
\text { Flavivirus }\end{array}$ & Tick (Ixodes spp.) & Humans, wildlife & $\mathrm{E}$ & Europe, Asia & No \\
\hline Thogoto virus & $\begin{array}{l}\text { Orthomyxoviridae } \\
\text { Thogotovirus }\end{array}$ & Tick (various spp.) & sheep & Abortion & Africa & No \\
\hline Usutu virus & $\begin{array}{l}\text { Flaviviridae } \\
\text { Flavivirus }\end{array}$ & Mosquito & Avian, humans & $\mathrm{E}$ & Africa, Europe & No \\
\hline $\begin{array}{l}\text { Venezuelan equine } \\
\text { encephalitis virus }\end{array}$ & $\begin{array}{l}\text { Togaviridae } \\
\text { Alphavirus }\end{array}$ & Mosquito & Humans, horse & $\mathrm{E}$ & Americas & Yes \\
\hline $\begin{array}{l}\text { Vesicular stomatitis } \\
\text { virus }\end{array}$ & $\begin{array}{l}\text { Rhabdoviridae } \\
\text { Vesiculovirus }\end{array}$ & $\begin{array}{l}\text { Mosquito/sandfly/ } \\
\text { midges/blackfly }\end{array}$ & $\begin{array}{l}\text { Humans, cattle, } \\
\text { horse, pigs }\end{array}$ & Mucosal vesicles & Americas & Yes \\
\hline Wesselsbron virus & $\begin{array}{l}\text { Flaviviridae } \\
\text { Flavivirus }\end{array}$ & Mosquito (Aedes spp.) & $\begin{array}{l}\text { Humans, sheep, } \\
\text { cattle }\end{array}$ & $\mathrm{HF}$ & Africa, Asia & No \\
\hline West Nile virus & $\begin{array}{l}\text { Flaviviridae } \\
\text { Flavivirus }\end{array}$ & Mosquito (Culex spp.) & $\begin{array}{l}\text { humans, cattle, } \\
\text { horse, avian }\end{array}$ & $\mathbf{E}$ & $\begin{array}{c}\text { Africa, Eurasia, } \\
\text { Americas }\end{array}$ & Yes \\
\hline $\begin{array}{l}\text { Western equine } \\
\text { encephalitis virus }\end{array}$ & $\begin{array}{l}\text { Togaviridae } \\
\text { Alphavirus }\end{array}$ & Mosquito & $\begin{array}{c}\text { Humans, cattle, } \\
\text { horse }\end{array}$ & $\mathrm{E}$ & Americas & Yes \\
\hline Yellow fever virus & $\begin{array}{l}\text { Flaviviridae } \\
\text { Flavivirus }\end{array}$ & $\begin{array}{c}\text { Mosquito (Aedes and } \\
\text { Haemagogus spp.) }\end{array}$ & Humans, primates & $\mathrm{HF}$ & $\begin{array}{c}\text { Africa, South } \\
\text { America, Caribbean }\end{array}$ & No \\
\hline
\end{tabular}

${ }^{1}$ SFI: systemic Febrile Illness; ${ }^{2} \mathrm{HF}$ : haemorrhagic fever; ${ }^{3} \mathrm{E}$ : encephalitis.

$*$ Office International des Epizooties (World Organisation for Animal Health).

\section{Viruses Associated with Transmission by Midges}

\subsection{Bluetongue Virus}

2.1.1. Clinical Disease. Bluetongue (BT) is a disease of ruminants with sheep being the most susceptible and affected species and cattle being affected to a lesser extent. Asymptomatic infections have been recorded in various other species such as deer, alpaca, llamas, and goats [17-19]. Since the emergence of BTV serotype 8 in northern Europe, significant clinical disease in cattle herds and goats has been reported [20]. The incubation period from exposure to disease is between two and fifteen days, averaging around 6 days [21]. In sheep, disease is first characterised by a fever and salivation, which develops into a more severe form causing mucopurulent discharge from the nasal passages and oedema of face and lips. The tongue may become cyanotic hence the name bluetongue and haemorrhages can form on the coronary band. Oral lesions can become haemorrhagic and ulcerative [21]. In affected cattle, crusts and erosions are visible on the nasal and oral mucosa, in or around the nostrils and lips. Other signs include salivation, fever, conjunctivitis, muscle necrosis, and stiffness in limbs.

2.1.2. Geographical Distribution. BTV is endemic throughout the world with the total of 24 serotypes circulating across the globe. In 2007, a new Orbivirus, Toggenburg virus, was isolated from goats in Switzerland and is now characterised as a tentative 25th serotype of bluetongue virus [22]. A further serotype has been detected in the Middle East [23].

Bluetongue virus was first reported in Africa when the disease was described in European Merino sheep that had been introduced into the Cape Colony [21]. Historically, the disease has predominantly been found between latitudes $40^{\circ} \mathrm{N}$ and $35^{\circ} \mathrm{S}$ until 1998 when the virus entered Europe and caused repeated outbreaks involving mainly five serotypes (BTV-1, BTV-2, BTV-4, BTV-9, and BTV-16) around the Mediterranean Basin affecting 12 European countries, three North African countries, and Israel [24]. In 2006, BTV-8 
emerged in northern Europe with outbreaks in most western European countries and as far north as Denmark and southern Sweden [25]. BTV-8 emerged in south-east England in 2007 and spread to locations throughout the UK. However, the UK government introduced a voluntary vaccination programme in 2008, which controlled the disease and no further outbreaks have been reported within the UK [26]. In 2008, small localised outbreaks of BTV serotype- 6 were reported in cattle herds in the Netherlands and Germany [27]. This was the second serotype to bypass southern Europe and emerge directly to northern Europe.

2.1.3. Vector. The only known biological vectors of bluetongue virus are the biting midges of the Culicoides genus. The most widespread vector is Afro-Asiatic C. imicola, which is distributed in Asia, the Middle East, most of Africa, and in southern and eastern Europe [28]. The absence and scarce distribution of $C$. imicola during the bluetongue outbreaks in Italy in 2000 onwards led to a search for novel vectors for virus transmission. Light-trapping and RTPCR experiments identified the C. pulicaris and C. obsoletus complex (C. obsoletus ss., C. chiopterus, C. dewulfi, C. scoticus) as potential vectors [29]. Later, field studies during the 2006 outbreak in Northern Europe also found no C. imicola in traps, but identified C. dewulfi, C. obsoletus, and C. scoticus as possible vectors [30]. In addition, these species have a palearctic distribution and they are known to be widespread throughout Europe. The high parity rates of $C$. dewulfi and $C$. obsoletus complex observed in Netherlands further supports the possibility of these species playing a role in bluetongue transmission [31]. These observations suggest that more than one species of midge are responsible for bluetongue virus distribution.

2.1.4. Molecular Diagnosis. Since the early 1990's, a range of RT-PCR assays targeting different BTV genome segments have been developed with a common drawback that they were only able to detect a limited number of serotypes [3237]. Furthermore, most of these methods required the use of agarose gel electrophoresis for nucleic acid detection, which made them laborious and unpractical for diagnostic purposes. However, the spread of BTV in Northern Europe has seen the reporting of a number of conventional [38] and real-time RT-PCR assays detecting all 24 serotypes simultaneously [39-41]. These assays have been designed for diagnostic requirements; they are all rapid, reliable, and sensitive, enabling high throughput testing, which can be applied directly to clinical samples. The genome of bluetongue virus consists of ten double-stranded RNA segments coding for seven structural and three nonstructural (NS) proteins [42]. Several of these genome segments are highly conserved within serotypes, which make them potential targets for molecular detection. All recently published realtime RT-PCR and traditional RT-PCR assays use different BTV genome segments as a target. Orrù and coworkers [37] designed an assay targeting genome segment 10 (encodes NS3) using a stem-loop Molecular Beacon (MB) fluorescent probe. The probe can be used for both real-time RT-PCR detection and quantification purposes. Two groups have published duplex assays using two primer sets, where one assay targets BTV genome segment 7 (encoding the main BTV-specific antigen, VP7) and the other targets the segment 1 (encoding the viral polymerase, VP1) [39]. Using genome segment 1 as a target not only allows detection of all 24 serotypes, but will also detect geographic variants within individual serotypes by differentiating the samples to eastern (Middle-East, Asia, Australasia) and western (Africa, The Americas) genotypes [39]. Considering the high genetic variability through reassortment and mutations of RNA viruses, it is possible that current real-time RT-PCR assays might fail to detect some strains of BTV in the future. To address the problem of the genetic variability of BTV, the most recent real-time RT-PCR assay is based on the primerprobe energy transfer (PriProET) which is characterised by its tolerance towards mutations in probe region [42]. This assay is designed to detect all 24 serotypes.

\subsection{African Horse Sickness Virus}

2.2.1. Clinical Disease. African horse sickness virus (AHSV) is the causative agent of African horse sickness, a disease of Equidae with a high level of mortality. Horses are the most affected species whereas mules and donkeys show mild clinical signs or no signs at all, and zebras are considered a natural host and reservoir for AHSV [43]. Based on clinical and pathological findings, African horse sickness can manifest in four forms ranging from mild symptoms with no mortality to a severe disease with $95 \%$ mortality rate [43]. The mildest form, horse sickness fever, is characterised by mild to moderate fever lasting up to 5 days and affecting most commonly the African donkey. A cardiac (subacute) form is recognised by long-lasting fever, oedema of the head, neck, chest, or supraorbital fossae and petechial haemorrhages in the eyes and tongue with mortality rates around $50 \%$. The most severe manifestation with highest mortality rates is a pulmonary (peracute) form, which is characterised by a rapid onset of disease. Death can occur without previous indication of illness or an animal can show signs of fever, depression and respiratory distress. The most commonly seen clinical presentation is a mixed (cardiac-pulmonary) form which can reach mortality rates as high as 70\% 3-6 days after onset of fever.

2.2.2. Geographical Distribution. The virus is currently endemic in subtropical and tropical areas of Africa below the Saharan desert, which seems to provide a natural barrier against spread northwards [43]. Nine serotypes have been recognised which all have been reported in southern and eastern Africa. Serotypes 4 and 9 are found in western Africa and are the only serotypes that have caused outbreaks outside of Africa. The major outbreaks outside Africa have so far occurred in the Middle East, Spain, and Portugal. Spain has experienced five outbreaks of African horse sickness since 1966 [44]. The first outbreak in 1966 started from Gibraltar and was caused by serotype 9, which resulted in 637 animals dying or being slaughtered. In 1987, a number of subclinically infected zebras were imported into a Safari park near Madrid, which caused four further outbreaks between 
1987 and 1990. However, these outbreaks were due to serotype 4 of AHSV. This was the first time that a serotype other than 9 had been recorded north of the Sahara desert. Before the eradication of the virus in Spain at the end of 1991, the outbreaks resulted in over 1300 horses dying or being destroyed and the virus spreading into Portugal, Tunisia, and Morocco [45].

2.2.3. Vector. Like bluetongue virus, African horse sickness virus is spread by biting midges of the Culicoides genus. The major vector for transmission is C. imicola, but also C. bolitinis has been shown to play a role in virus spread [46]. In 1998, over 100 horses died in an isolated population in Clarens Valley in South Africa and AHSV was isolated from the most locally abundant midge species, C. bolitinis, collected during light trap studies. It has been suggested that other Culicoides species might be involved, especially where low-grade cycling of virus is occurring.

2.2.4. Molecular Diagnosis. The first RT-PCR assays for AHSV detection and serogroup identification were time consuming and labour intensive procedures which involved either restriction fragment length polymorphism (RFLP) or dot-blot hybridisation assays [47-49]. These were followed by several conventional RT-PCR assays, which still required gel-based visualisation and took between four and six hours to complete [50-52]. However, a huge improvement in molecular diagnosis has occurred during recent years, resulting in numerous real-time RT-PCR assays that are able to detect, quantify, and discriminate the serotypes of AHSV in a short period of time [53-57]. Currently AHSV is only endemic in Africa, where laboratory conditions vary and real-time RT-PCR equipment can be too costly. Therefore, some studies have aimed to develop both real-time RTPCR and conventional RT-PCR in parallel or solely improve conventional RT-PCR to provide better and faster diagnostic tools that are available in all circumstances [58]. These studies have shown high sensitivity and specificity of both conventional and real-time RT-PCR assays for all nine serotypes. Detection limit for both conventional and TaqMan real-time RT-PCR has been reported to be $1.2 \mathrm{TCID}_{50} / \mathrm{mL}$ [55]. More importantly new, improved RT-PCR assays can provide results within three hours of sample receipt.

\subsection{Epizootic Haemorrhagic Fever Virus}

2.3.1. Clinical Disease. Epizootic haemorrhagic fever virus (EHDV) causes a haemorrhagic disease in ruminants, especially in white-tailed deer in America and in cattle elsewhere. The clinical signs are often similar to those caused by bluetongue virus which complicates diagnosis. The clinical signs reported in cattle include reduction in milk production, fever, loss of appetite, weakness, excessive nasal and ocular discharge, oral ulcerations, discolouration of the udder, and oedema of hooves [59].

2.3.2. Geographical Distribution. There are currently ten serotypes of EHDV circulating throughout the world. EHDV-1 was first isolated in white-tailed deer in New Jersey in 1955 and it is still the most important infectious disease in deer in North America. All serotypes have caused clinical disease in cattle across the globe including North America, Africa (north and south), Australia [60], the island of Réunion [61], and Japan. Recent outbreaks have been reported around the Mediterranean including Morocco, Algeria, Israel in 2006, and Turkey in 2007 [62].

2.3.3. Vector. Culicoides spp. transmit the disease between ruminant hosts.

2.3.4. Molecular Diagnosis. The earliest EHDV RT-PCR assays have been based on American isolates, mainly on serotypes 1 and 2 targeting different genomic segments [6365]. Since the spread of EHDV into new territories, the RT-PCR assays reported have been type-specific rather than serotype specific or even multiplex RT-PCR assays that can simultaneously detect both bluetongue and EHDV $[66,67]$. A real-time RT-PCR has been reported that detects eight serotypes of EHDV [68].

\subsection{Bovine Ephemeral Fever Virus}

2.4.1. Clinical Disease. Bovine ephemeral fever virus (BEFV) causes disease in domestic cattle and water buffalo [69]. The disease is also known by the names 3-day sickness, stiff sickness, bovine epizootic fever, lazy man's disease, or dengue of cattle. The clinical outcome can vary from inapparent infection to death, but generally disease has four main phases. After an incubation period of between one and ten days, disease begins with a sudden fever that can be bi-, tri, or polyphasic with peaks 12 to 18 hours apart. Fever lasts around half a day before the infected animal may become depressed and reluctant to move. Mucous discharge from the nose and profuse salivation can be observed and milk production is reduced or ceased altogether. This period of disability usually lasts between one and two days after which most animals start to recover. Although mortality rates as high as $30 \%$ have been observed, in most uncomplicated cases it is less than $2 \%$. Sequelae include reduced milk production and other complications include pneumonia, mastitis, abortion in late pregnancy and temporary infertility of bulls [70].

2.4.2. Geographical Distribution. The bovine ephemeral fever was first recognised in Zimbabwe in 1906. The current distribution of BEFV includes all of Africa, the Middle East, Asia, and Australasia [71]. The outbreaks in the Middle East have occurred in Saudi Arabia and Israel $[72,73]$. The disease has not been reported in Europe or the Americas.

2.4.3. Vector. Epidemiological studies indicate that BEFV is transmitted through flying insects. No arthropod vector has been shown to transmit the virus, but it has been isolated from Culicoides midges in Kenya and mosquitoes (Culicine mosquito species and Anopheles bancroftii) in Australia [74, 75]. 
2.4.4. Molecular Diagnosis. Currently, virus isolation seems to be the standard method for bovine ephemeral fever diagnosis and only two molecular diagnostic assays detecting BEFV have been reported. Real-time RT-PCR has been developed by Stram and coworkers [76], whereas Zheng and coworkers [77] reported the development of reverse transcription loop-mediated isothermal amplification (RTLAMP) method. Both assays target the $\mathrm{G}$ gene and are highly sensitive assays, real-time RT-PCR being able to detect 10 BEFV genome copies in a sample [76]. The advantage of RTLAMP is that no specialist equipment is required as there is no requirement for thermal cycling. However, a range of specialist apparatus is now available specifically for application with RT-LAMP such as lateral flow devices and turbidometers.

\subsection{Akabane Virus}

2.5.1. Disease. Akabane is a disease of ruminants. In adults the disease is generally asymptomatic with a transient viraemia occurring between one and six days after infection, which lasts for about six days. Occasional cases of encephalomyelitis have been observed in some infected animals [78]. The main economic impact of Akabane virus results from abortions, stillbirths, and congenital abnormalities that affect pregnant animals. Abnormalities vary depending on the trimester when infection occurs, although most are severely affected and euthanized shortly after birth.

2.5.2. Geographical Distribution. The disease occurs between latitudes $35^{\circ} \mathrm{N}$ and $35^{\circ} \mathrm{S}$ [79]. Serological evidence indicates that the virus is present throughout Africa, Asia, and the northern half of Australia. Disease has been observed in South Africa, Cyprus, the Middle East, and Japan.

2.5.3. Vector. Akabane virus has been isolated from Culicoides spp. in Australia (C. brevitarsis and C. wadei), Africa (C. milnei and C. imicola), Japan (C. oxystoma), and a number of mosquito species including Aedes vexans, Culex tritaeniorhynchus and Anopheles funestus.

2.5.4. Molecular Diagnosis. The genome of Akabane virus, like other orthobunyaviruses, is segmented, consisting of a small (s), medium (m), and large (l) segments. Standard RTPCR assays have been described for detection of Akabane virus that target the $S$ segment of the virus $[78,80]$. A further development has been to incorporate detection of Akabane virus with that of Aino virus, a causative agent of congenital defects in cattle. This combined assay takes the format of a real-time multiplex RT-PCR that also targets the S segment [81]. The limit of detection is reported to be between 3 and 30 genome copies.

\subsection{Equine Encephalosis Virus}

2.6.1. Disease. Equine encephalosis virus (EEV) causes an acute disease in horses with a high fever and depressed appetite. A characteristic of the disease is the swelling of the lips and eyelids. Neurological disease is common and abor- tion can result from infection. Clinical features such as oedema are similar to those observed for AHSV and this should be considered in the diagnosis. However, fatalities are rare, particularly when supportive treatment is provided.

2.6.2. Geographical Distribution. The virus was originally isolated in South Africa and seven serotypes have been reported within the country [82]. A recent report has suggested the emergence of EEV in Israel [83].

2.6.3. Vector. Culicoides spp. are implicated in the transmission of this virus [84].

2.6.4. Molecular Diagnosis. No specific RT-PCR assays have been reported for equine encephalosis virus.

\subsection{Vesicular Stomatitis Virus}

2.7.1. Disease. Vesicular stomatitis virus (VSV) causes disease in cattle, horses, and pigs and is significant as it is clinically similar to foot and mouth disease (FMD). The initial incubation period is between two and eight days with a fever that often goes undetected. Early signs include drooling and frothing at the mouth. Blister-like lesions form in the mouth, on the dental pad, the tongue, the lips, the nostrils, the hooves, and the teats. Oral lesions can be sufficiently painful to cause the infected animal to refuse food and weight loss can occur. Infection is not fatal, although recovery from acute disease can take two weeks and ulceration can take months to heal.

2.7.2. Geographical Distribution. The virus is endemic in Central America and northern South America. Sporadic outbreaks occur in the USA and western regions of South America [85].

2.7.3. Vector. A range of haematophagus insects have been associated with transmission of VSV including Sand flies (Diptera: Psychodidae), black flies (Diptera: Simulidae), mosquitoes (Diptera: Culicidae), and culicoides midges (Diptera: Ceratopogonidae) [86]. Experimentally, only the sand fly (Lutzomyia shannoni) and the black fly (Simulium vittatum) have been shown to transmit the virus transovarially or to susceptible hosts. Serological evidence suggests that wild mammals can be infected with VSV but as yet there is no clear wildlife reservoir for the disease.

2.7.4. Molecular Diagnosis. Multiplex, real-time RT-PCRs have been devised to detect and differentiate different serotypes of VSV [86] and differentiate VSV from FMDV within the same assay [87].

\section{Viruses Associated with Transmission by Mosquitoes}

\subsection{Eastern, Venezuelan, and Western Equine Encephalitis Virus}

3.1.1. Disease. All three viruses cause disease in horses and humans [88]. This can range from asymptomatic infection 
to acute, sometimes fatal, encephalitis. VEEV in particular has caused extensive epizootics in some regions of South America (Venezuala and Colombia).

3.1.2. Geographical Distribution. EEEV has been reported from the Eastern USA, Caribbean, South, and Central America. WEEV has been reported from North America and Cuba. VEEV is reported from many regions of South and Central America.

\subsubsection{Vector}

$E E E V$. The mosquito vector varies with climate and geography. In temperate zones, the ornithophagic Culiseta melanura is the main vector. In tropical regions, EEEV has been isolated from Culex melanoconion.

WEEV. In North America Culex tarsalis is considered the main vector of transmission between avian species. Aedes spp. have also been implicated in transmission to mammals. In South America Aedes albifasciatus has been reported as a vector.

VEEV. Culex melanoconion is associated with transmission of VEEV.

3.1.4. Molecular Diagnosis. TaqMan assays for North American EEEV and WEEV have been described [89]. Primer sets that detect a range of alphaviruses, including EEEV and VEEV have been described [90], however, this was linked to final detection using electrospray ionization mass spectrometry.

\subsection{Japanese Encephalitis Virus}

3.2.1. Disease. Japanese encephalitis virus (JEV) is asymptomatic in adult pigs but causes abortion, still-birth, and birth defects including central nervous system defects resulting in economic loss [91]. The virus also causes encephalitic disease in humans with over 50,000 cases reported annually [92]. Occasional cases in equines have been reported [93].

3.2.2. Geographical Distribution. JEV is found throughout Asia from Pakistan to Japan [94]. There is evidence that the virus is dispersing westwards through Asia.

3.2.3. Vector. The main vector of JEV is Culex tritaeniorrhyncus, which favours breeding in rice paddies. C. gelidus complex mosquitoes enable transmission to birds which assists in maintaining the virus in the environment [95].

3.2.4. Molecular Diagnosis. A real-time RT-PCR [96] that targets the 3 untranslated regions has been reported with detection to $112 \mathrm{TCID}_{50} / \mathrm{mL}$. A multiplex real-time RT-PCR for detection of JEV, yellow fever virus, West Nile virus, dengue virus (serotypes 1-4), and St. Louis encephalitis virus has been reported [97] with a sensitivity of 2 PFU/mL. Realtime RT-LAMP $[98,99]$ assays have been developed for detection of JEV with detection levels as low as 0.1 PFU.

\subsection{Rift Valley Fever Virus}

3.3.1. Disease. Rift Valley fever virus (RVFV) affects ruminants with susceptibility influenced by age. Newborn animals are highly susceptible with adults showing less severe disease [100]. The incubation period ranges from one to three days followed by fever, recumbency, and haemorrhagic diarrhoea. Mortality can reach $70 \%$. High rates of abortion are also associated with epidemics of Rift Valley haemorrhagic fever (RVHF), often described as abortion storms. The virus causes disease in humans ranging from uncomplicated influenza-like illness to haemorrhagic fever with liver damage and occasionally encephalitis.

3.3.2. Geographical Distribution. The virus is considered endemic throughout much of Africa, although clinical disease occurs infrequently. However, sudden outbreaks with high livestock mortality occur in many regions often following flooding. The disease was first reported in East Africa (Kenya and Tanzania) but is believed to have expanded its range north, west, and south, characterised by sudden epidemics [101]. There has been a well-documented outbreak of RVHF in the Arabian Peninsula associated with livestock movements from East Africa [102].

3.3.3. Vector. Aedes spp. are the principal virus vector for livestock and are believed to maintain the virus between epidemics although other species are capable of acting as bridge vectors enabling transmission during epidemics, such as Culex spp.

3.3.4. Molecular Diagnosis. Numerous real-time RT-PCR methods have been developed for rapid detection of RVFV [103-106]. The detection limit of these assays is typically between 10 and 100 genome copies. An alternative approach is the use of reverse transcription loop-mediated isothermal amplification (RT-LAMP) technique $[107,108]$. The detection limits of RT-LAMP assays are comparable to real-time RT-PCR.

\subsection{Wesselsbron Virus}

3.4.1. Disease. Wesselsbron virus (WSLV) causes infection in sheep and goats and is associated with abortion and congenital abnormalities [109-111]. In adult animals, infection is usually subclinical, although in newborn animals clinical disease can result after a one to three day incubation period with fever and anorexia. Mortality can reach as high as $27 \%$. Infection in humans has been reported following laboratory exposure and causes a mild influenza-like illness.

3.4.2. Geographical Distribution. Virus isolation and seroprevalence studies suggest that the virus is present across Africa $[112,113]$.

3.4.3. Vector. Aedes spp. are considered the main vector for Wesselsbron virus. In a recent study over 50 isolates of WSLV were isolated from Aedes vexans collected in Mauritania and Senegal [113]. 
3.4.4. Molecular Diagnosis. No specific RT-PCR tests have been reported, although the Wesselsbron virus genome has been published (NCBI Reference Sequence: NC_012735). Wesselsbron virus can be detected by RT-PCR using universal flavivirus primers and sequencing [114].

\subsection{West Nile Virus}

3.5.1. Disease. West Nile virus (WNV) causes encephalitic disease in horses, humans and some avian species [115]. In horses early disease consists of fever that is usually inapparent. Subsequent disease is neurological including ataxia, paresis and limb paralysis leading to recumbence. Muscle tremor and muscle rigidity may be observed. Mortality rates vary and may be particularly high in the USA reaching over $55 \%$.

3.5.2. Geographical Distribution. Until recently, WNV was an Old World disease present throughout Africa and Asia with occasional incursions into Europe around the Mediterranean Basin [116]. However, in 1999, the virus emerged in the north east USA and spread throughout the Americas [117] and has remained endemic since that time [118].

3.5.3. Vector. The principal vector for WNV is the ornithophilic mosquito Culex pipiens. However, a wide range of mosquito species have been shown to support virus replication and transmit virus to mammalian species [119].

3.5.4. Molecular Diagnosis. Molecular detection of WNV has been reviewed recently by Shi and Kramer [120]. Such assays usually detect between 40 and 100 genome copies, although some suggest that sensitivity can be even lower [121]. Further developments have enabled multiplexing with other arboviral diseases [122, 123] and improved assay sensitivity [124] suggesting that the detection limit is 0.07 genome copies/mL. RT-LAMP assays have been developed for WNV [125] and used to detect the virus in mosquito samples [126]. The sensitivity limit of these assays has been reported to be approximately $0.1 \mathrm{PFU}$.

\section{Viruses Associated with Transmission by Ticks}

\subsection{African Swine Fever Virus}

4.1.1. Clinical Disease. African swine fever virus infects warthogs and bush pigs in Africa with no clinical disease, but domestic pigs can succumb to severe infection with an incubation period of five to fifteen days [127]. The disease can manifest in any one of four forms depending on the virulence of a strain. Highly virulent strains cause peracute and acute infections with clinical signs of high fever, anorexia, diarrhoea, recumbency, and general reddening of skin or discoloration on the ventral chest and abdomen, tips of the ears or tail, and on distal limbs. Death can occur within a day, sometimes before obvious clinical signs. The less virulent strains cause subacute and chronic infection. The subacute form manifests as a mild illness with an intermittent fever lasting approximately one month although pregnant animals might abort. In chronic cases, low fever, pneumonia and swelling of joints may occur. Some animals infected with low virulence strains can seroconvert without any clinical symptoms. Morbidity rates can reach close to $100 \%$ in herds that are naïve for ASFV whereas mortality rates vary, but can be as high as $100 \%$, depending on virulence of the strain. Those animals that have survived acute or chronic disease can become persistently infected and act as carriers for the virus.

4.1.2. Geographical Distribution. African swine fever has been reported in Africa since the 1890's and is endemic in most parts of sub-Saharan Africa where transmission appears in three different forms; a sylvatic cycle, a domestic pig cycle and a pig-tick cycle [128, 129]. In 1958, ASFV emerged for the first time in Europe in Portugal before spreading to Spain in 1960, where it caused several outbreaks until the disease was finally eradicated [130]. In 1967, virus was detected in Italy and in 1978 ASF outbreaks occurred simultaneously in Malta and Sardinia. Whereas disease was eradicated from Malta and mainland Italy, ASF remains endemic in Sardinia where it is established in free-range pigs and wild boars. In 1998, Madagascar reported the first case of African swine fever [131], and from the year 2000 onwards virus has continued to spread into new territories including Georgia, Iran, and Mauritius [132-134]. The Georgian outbreak in 2007 demonstrated perfectly the emerging and transboundary characteristics of ASFV, as within a year virus spread from Georgia to several neighboring countries including Armenia, Azerbaijan, and the Russian Republic of Chechnya [132]. In the following year, virus spread to northwestern Iran where it caused an outbreak in wild boar [133]. Other short-lived, sporadic outbreaks have been reported from France, Belgium, Netherlands, Caribbean, and South America.

4.1.3. Vector and Transmission. The subclinical infection of ASFV in warthogs and bush pigs is maintained by soft ticks of the genus Ornithodoros. In Africa, the main vector is $O$. moubata, whereas in Southern Europe ASFV is transmitted by O. erraticus [135]. O. moubata is most abundant in eastern and southern Africa particularly in Cameroon, Central African Republic, and Sudan. The most prevalent viral hosts include warthogs, domestic pigs, and man. Although, ticks do play a part in virus transmission, the epidemiological role is thought to be low, especially in those areas where tick populations are small [134]. The more likely route of virus spread is through direct oronasal contact with an infected animal or indirectly via fomites and contaminated pig feed. The most recent outbreaks in previously ASFV-free areas could have been transmitted through feed products containing infected pig meat.

4.1.4. Molecular Detection. As there is no cure or vaccine for ASFV, slaughter is the only tool for control and eradication of this highly contagious virus in infected areas. Therefore, fast and reliable laboratory diagnosis is required to limit the socio-economic burden of outbreaks. Furthermore, highly specific, differential diagnosis of disease is necessary, 
as clinical signs of African swine fever may resemble those of other infections, especially classical swine fever. The current OIE manual recommends Taqman real-time PCR such as the assay developed by King and coworkers [136]. As realtime PCRs are high throughput, sensitive, specific, and quick to run, recent development of these assays has focused on improvement of existing real-time assays by applying varying PCR chemistries. This has led to several modifications of real-time PCR including use of minor groove binding probes or molecular beacon assays $[137,138]$. A recent method has been further developed with field diagnostics in mind. Two assays, a LAMP method and a linear-after-the-exponential PCR (LATE-PCR), have both been adapted for use in field conditions [139, 140]. These methods could considerably shorten the time between infection and diagnosis as there is no requirement for samples to be transported to the laboratory.

\subsection{Crimean-Congo Haemorrhagic Fever Virus}

4.2.1. Disease. Crimean-Congo haemorrhagic fever (CCHF) is one the most important and widespread diseases caused by tick-borne viruses. The causative agent, Crimean-Congo haemorrhagic fever virus does not cause disease in livestock, but vertebrates play a role in virus transmission as part of a tick-vertebrate-tick enzootic cycle [141]. Although there is no evidence of clinical disease in animals, contact with viremic animals, tick bite, or crushing ticks taken from infected animals can lead to human infection. In humans, $\mathrm{CCHF}$ virus causes a disease with four phases: incubation, prehaemorrhagic, haemorrhagic, and convalescence phases [141]. Following the short incubation period (3-7 days), sudden onset of fever, headaches, myalgia, and dizziness occur $[142,143]$. A few days later, a rapidly developing haemorrhagic period occurs, with haematomas appearing on the skin and mucous membranes with mortality rates ranging from $3 \%$ to $30 \%$. The surviving patients will go through the convalescence period lasting 9-10 days which can include variable symptoms such as tachycardia, temporary hair loss, poor vision, and loss of appetite. Infected humans can spread $\mathrm{CCHF}$ via close contacts resulting in community and nosocomial outbreaks [144-148]. Furthermore, individuals in certain occupations such as health carers, veterinarians, farmers, and abattoir workers are at increased risk of contracting Crimean-Congo haemorrhagic fever [141, 143, 149].

4.2.2. Geographical Distribution. The geographic distribution of CCHF virus is the widest amongst all tick-borne diseases. Currently CCHFV is endemic in Africa, Asia, Balkan countries, and Middle and Far East [142, 145, 150]. During the last ten years, CCHFV has been rapidly introduced into new, previously nonendemic areas; especially into eastern and southeastern Europe including Greece and Turkey [149, 151-153].

4.2.3. Vector. Hyalomma spp. are the vector and reservoir for CCHFV, particularly Hyalomma marginatum. The geographical distribution of these ticks closely match the distribution of CCHFV and covers southern Europe, southern Russia extending to southern Asia, and most of Africa [154]. The host range of these ticks varies from domestic animals (cattle, horse, sheep, and goats) for adults to small wild animals and birds for larvae and nymphs.

4.2.4. Molecular Detection. Since the mid 1990's several nested and real-time RT-PCR assays, which all target genomic $S$ segment of the tripartite genome. These assays have been developed to achieve fast initial and differential laboratory diagnosis of CCHFV [104, 155-158]. Both the nested and real-time RT-PCR assays are comparable in terms of sensitivity, but the results can be achieved in two hours with one-step real-time RT-PCR, whereas it takes 4-5 hours to run nested RT-PCR without gel electrophoresis. Due to the high genetic variability of CCHFV isolates, the first realtime RT-PCR assay detecting CCHFV was based on a Sybr Green method that intercalates to any double stranded DNA and requires identification of the positive product using gel electrophoresis [104]. More specific assays can be developed by designing primers and probes directed at strains of interest, for example, those circulating in geographically defined areas. Strains from the Balkan region have been successfully identified by using a one-step real-time RT-PCR that is based on the fluorescence resonance energy transfer (FRET) probe technology employing the endonuclease $\left(5^{\prime} \rightarrow 3^{\prime}\right)$ activity of Taq polymerase enzyme [158]. Furthermore, this assay can also be used for detection of CCHFV from ticks.

\subsection{Nairobi Sheep Disease Virus}

4.3.1. Disease. Nairobi sheep disease virus (NSDV) causes acute haemorrhagic gastroenteritis in sheep and goats. This is a severe and fatal disease with mortality rates reaching over 90 percent in non-immune animals. The short incubation period (2-4 days) is followed by high fever, diarrhoea, and collapse [159]. Watery to mucoid and bloody diarrhoea is seen 2-4 days after the onset of fever which itself can last up to 8 days. As the disease progresses nasal discharge and conjunctivitis are common features [160]. In pregnant animals, the infection can lead to abortion. In fatal cases, death often occurs in the early stages of a disease. A variant of NSDV, Ganjam virus has been isolated in India [161]. This virus is highly pathogenic in exotic and crossbred sheep and goats causing a disease with high fever, dullness, depression, and loss of appetite [162].

4.3.2. Geographical Distribution. Nairobi sheep disease has been reported since 1910 when it was first identified near Nairobi in Kenya [163]. NSDV is now mostly enzootic in Kenya with the majority of indigenous sheep and goats having protective antibodies, and outbreaks tend to occur when flocks from uninfected areas are brought into enzootic areas [164]. Further outbreaks have been reported from other countries in east and central Africa. Serosurveys suggest that the virus may be more widespread in countries of Southern Africa [165]. Ganjam virus, a variant of NSDV, circulates across southern India [166].

4.3.3. Vector. In Africa, the main vector for NSDV is the three-host Ixodid tick Rhipicephalus appendiculatus, which 
is found between its northern limits of southern Sudan and Ethiopia through Eastern, central and Southern Africa. Livestock hosts for this tick include cattle, sheep, goats, and horses [164]. In wildlife, antelopes and buffalo are frequently infested. Ganjam virus has been isolated from Haemaphysalis spp. ticks, which have been collected from sheep and goats in India [161].

4.3.4. Molecular Detection. Primers for NSDV amplification have been reported $[166,167]$. The complete genome sequences of the tripartite genome of NSDV have been published. No real-time RT-PCR has been reported.

\subsection{Louping Ill Virus}

4.4.1. Disease. The main forms of tick-borne encephalitis virus (TBEV) found in Europe and Asia do not cause clinical disease in livestock although human cases are on the increase in Europe [168]. However, a number of closely related variants of TBEV cause disease in livestock. These include louping ill virus (LIV), Spanish sheep encephalitis virus (SSEV), Greek goat encephalitis virus (GGEV), and Turkish tick-borne encephalitis virus (TTEV). Of these, LIV is the most studied virus as the cause of disease in sheep and red grouse. In red grouse, LIV causes rapid and fatal encephalitis whereas in sheep, disease is biphasic, especially in young nonimmune animals [169]. The initial clinical signs of louping ill include fever and weakness before animals develop neurological signs of disease. A range between 5 and $60 \%$ of infected animals develop clinical signs and death can occur between 24 and 48 hours following the development of neurological signs. During the neurological phase, the most damage is caused to the cerebellum. Clinically, the second phase is characterized by cerebral ataxia, hyperexcitability, and progressive paralysis [169]. Occasionally, natural infection of louping ill has also been reported from other species such as dogs, roe and red deer, and llamas [170-173]. The other variants are genetically distinct, but closely related to louping ill. They are much less studied, but appear to all cause disease that resembles louping ill [174].

4.4.2. Geographical Distribution. Tick-borne encephalitis virus is found in many areas throughout Europe and Asia. Transmission to humans is mainly through tick bites but can occasionally result from consumption of unpasteurized milk [175]. LIV is endemic within upland areas in the UK, particularly in Scotland, Wales, the northwest and southwest of England [169]. There have also been reports of LIV in Ireland and Norway [176]. Sheep infected with SSEV have been reported from the Basque region of Spain [174, 177]. The first isolation of GGEV was made in the village of Vergina in northern Greece [178]. Subsequent studies have suggested that GGEV circulates in the I. ricinus population in northern Greece, although at low density [179]. TTEV was first reported from northwestern Turkey (Anatolia) as encephalitis in sheep and was subsequent confirmed by nucleotide analysis to be related to tick-borne encephalitis virus [180-182].
4.4.3. Vector. Both TBEV and its variants are transmitted by the three-host hard tick Ixodes ricinus in Europe. These ticks are the most common species of ticks in northwest Europe and are also known as the common sheep tick, castor bean tick or wood tick. In addition to sheep and red grouse, the hosts for I. ricinus in the UK include mountain hares, red deer, roe deer and small mammals [183]. In the Far East of Europe and throughout Asia, TBEV is transmitted by Ixodes persulcatus.

4.4.4. Molecular Detection. The first nested one-step RTPCR for louping ill detection was developed in mid-1990s. This assay, which targets the envelope (E) and membrane (M) genes of the virus genome, can be used for virus identification in ticks and other species [184]. As the E gene is the most conserved of the three LIV structural genes, a onestep Taqman RT-PCR assay has been developed with primers for this protein [185]. Brain and spinal cord samples were tested and detection limit of $1 \mathrm{PFU} / \mathrm{mL}$ was achieved, making this assay as sensitive as the traditional plaque assay. In recent years, real-time RT-PCR assay detecting eight different tickborne flaviviruses (including louping ill) and West Nile virus has been developed in the UK [186]. The assay employs degenerate primers targeting nonstructural protein 5 and is based on incorporation of Sybr green. The assay is not as sensitive as species specific assays, but makes it an ideal choice when a single virus cannot be specified before testing [186]. A recently reported assay uses one-step real-time RT-PCR with pyrosequencing which enables the rapid differentiation between TBEV subtypes [187]. Although, this assay was developed to differentiate between the main TBE subtypes, it is also able to detect louping ill virus. Specific detection assays for SSEV, TTEV, and GGEV have not been reported.

\section{Conclusions}

The majority of the viruses reviewed have been thoroughly characterized and there are a wide range of molecular diagnostic tests available. These include bluetongue virus, AHSV, VSV, WNV, and ASFV. These tend to be those viruses that cause the greatest impact either to livestock health or as a consequence of spillover into the human population as a zoonotic agent. New serotypes and variants emerge and techniques may require modification or augmentation in response to genetic differences. Other viruses have molecular tests available, but these are not widely in use, either because many countries do not consider them necessary or do not have suitable containment facilities to handle the virus. This group includes EHFV, BEFV, Akabane virus, the equine encephalitides, JEV, RVFV, CCHFV, and variants of tickborne encephalitis virus. Further effort is needed to establish molecular tests for these viruses more widely in preparation for potential outbreaks. Finally, there is a small group for which no molecular diagnostic tests have been reported. This includes equine encephalosis virus, Wesselsbron disease virus and Nairobi sheep disease virus. These viruses require some test development.

Test development and implementation could take two forms. The first option is to develop specific tests that detect 
a single virus, often at high sensitivity. The alternative is the development of assays that detect a range of related pathogens in single step. This has been applied to groups including the flaviviruses, alphaviruses, and phleboviruses. The latter option has the benefit of screening for more than one pathogen. However, this approach is often less sensitive and may require further analysis to identify the exact virus involved.

Currently, rapid detection methods are dominated by nucleic acid amplification methods, particularly the polymerase chain reaction. By linking nucleic acid amplification to sequencing, it is possible to rapidly identify a large number of potential pathogenic viruses $[114,188]$. This approach has been applied to detection of flaviviruses using universal primers ([186], and references therein). New technologies such as microarray [189] and next generation sequencing [190] are being applied to the investigation of infectious viruses. However, these technologies are expensive to establish and maintain for purely diagnostic or surveillance purposes. Future development is required in this area to make these technologies more accessible and affordable for use in the detection of arthropod viruses of livestock.

\section{Acknowledgments}

This study was funded by Defra Grant SE0530. The authors would also like to thank the reviewers of this paper for their numerous constructive comments.

\section{References}

[1] S. Odend' Hal, The Geographical Distribution of Animal Viral Diseases, Academic Press, New York, NY, USA, 1983.

[2] D. J. Gubler, "Human arbovirus infections worldwide," Annals of the New York Academy of Sciences, vol. 951, pp. 13$24,2001$.

[3] L. D. Kramer, L. M. Styer, and G. D. Ebel, "A global perspective on the epidemiology of West Nile virus," Annual Review of Entomology, vol. 53, pp. 61-81, 2008.

[4] S. Carpenter, A. Wilson, and P. S. Mellor, "Culicoides and the emergence of bluetongue virus in northern Europe," Trends in Microbiology, vol. 17, no. 4, pp. 172-178, 2009.

[5] E. A. Gould, S. Higgs, A. Buckley, and T. S. Gritsun, "Potential arbovirus emergence and implications for the United Kingdom," Emerging Infectious Diseases, vol. 12, no. 4, pp. 549-555, 2006.

[6] R. M. Vorou, V. G. Papavassiliou, and S. Tsiodras, "Emerging zoonoses and vector-borne infections affecting humans in Europe," Epidemiology and Infection, vol. 135, no. 8, pp. 1231-1247, 2007.

[7] J. M. Medlock, K. R. Snow, and S. Leach, "Possible ecology and epidemiology of medically important mosquito-borne arboviruses in Great Britain," Epidemiology and Infection, vol. 135, no. 3, pp. 466-482, 2007.

[8] E. Gould and T. Solomon, "Pathogenic flaviviruses," The Lancet, vol. 371, no. 9611, pp. 500-509, 2008.

[9] P. Gale, T. Drew, L. P. Phipps, G. David, and M. Wooldridge, "The effect of climate change on the occurrence and prevalence of livestock diseases in Great Britain," Journal of Applied Microbiology, vol. 106, no. 5, pp. 1409-1423, 2009.
[10] K. McGuire, E. C. Holmes, G. F. Gao, H. W. Reid, and E. A. Gould, "Tracing the origins of louping ill virus by molecular phylogenetic analysis," Journal of General Virology, vol. 79, no. 5, pp. 981-988, 1998.

[11] A. Buckley, A. Dawson, S. R. Moss, S. A. Hinsley, P. E. Bellamy, and E. A. Gould, "Serological evidence of West Nile virus, Usutu virus and Sindbis virus infection of birds in the UK," Journal of General Virology, vol. 84, no. 10, pp. 28072817, 2003.

[12] G. L. Autorino, A. Battisti, V. Deubel et al., "West Nile virus epidemic in horses, Tuscany region, Italy," Emerging Infectious Diseases, vol. 8, no. 12, pp. 1372-1378, 2002.

[13] F. Monarco, G. Savini, P. Calistri et al., "2009 West Nile disease epidemic in Italy: first evidence of overwintering in Western Europe?" Research in Veterinary Science, vol. 91, pp. 321-326, 2011.

[14] Z. Hubálek, "An annotated checklist of pathogenic microorganisms associated with migratory birds," Journal of Wildlife Diseases, vol. 40, no. 4, pp. 639-659, 2004.

[15] J. Waldenström, A. Lundkvist, K. I. Falk et al., "Migrating birds and tickborne encephalitis virus," Emerging Infectious Diseases, vol. 13, no. 8, pp. 1215-1218, 2007.

[16] C. Saegerman, D. Berkvens, and P. S. Mellor, "Bluetongue epidemiology in the European Union," Emerging Infectious Diseases, vol. 14, no. 4, pp. 539-544, 2008.

[17] M. Henrich, M. Reinacher, and H. P. Hamann, "Lethal bluetongue virus infection in an alpaca," Veterinary Record, vol. 161, no. 22, p. 764, 2007.

[18] N. J. Maclachlan, C. P. Drew, K. E. Darpel, and G. Worwa, "The Pathology and Pathogenesis of Bluetongue," Journal of Comparative Pathology, vol. 141, no. 1, pp. 1-16, 2009.

[19] G. Meyer, C. Lacroux, S. Léger et al., "Lethal bluetongue virus serotype 1 infection in llamas," Emerging Infectious Diseases, vol. 15, no. 4, pp. 608-610, 2009.

[20] D. Dercksen, N. G. Nibbelink, R. Paauwe, A. Backx, P. Van Rijn, and P. Vellema, "First outbreak of bluetongue in goats in the Netherlands," Tijdschrift voor Diergeneeskunde, vol. 132, no. 20, pp. 786-790, 2007.

[21] B. J. Erasmus, "Bluetongue in sheep and goats," Australian veterinary journal, vol. 51, no. 4, pp. 165-170, 1975.

[22] M. A. Hofmann, S. Renzullo, M. Mader, V. Chaignat, G. Worwa, and B. Thuer, "Genetic characterization of toggenburg orbivirus, a new bluetongue virus, from goats, Switzerland," Emerging Infectious Diseases, vol. 14, no. 12, pp. 18551861, 2008.

[23] S. Maan, N. S. Maan, K. Nomikou et al., "Novel bluetongue virus serotype from Kuwait," Emerging Infectious Diseases, vol. 17, pp. 886-889, 2011.

[24] P. S. Mellor, S. Carpenter, L. Harrup, M. Baylis, and P. P. C. Mertens, "Bluetongue in Europe and the Mediterranean Basin: history of occurrence prior to 2006," Preventive Veterinary Medicine, vol. 87, no. 1-2, pp. 4-20, 2008.

[25] S. Sternberg Lewerin, G. Hallgren, K. Mieziewska, L. T. Berndtsson, J. Chirico, and M. Elvander, "Infection with bluetongue virus serotype 8 in Sweden in 2008," The Veterinary Record, vol. 167, no. 5, pp. 165-170, 2010.

[26] C. Szmaragd, A. J. Wilson, S. Carpenter, J. L. N. Wood, P. S. Mellor, and S. Gubbins, "The spread of bluetongue virus serotype 8 in Great Britain and its control by vaccination," PLoS ONE, vol. 5, no. 2, article e9353, 2010.

[27] S. Maan, N. S. Maan, P. A. van Rijn et al., "Full genome characterisation of bluetongue virus serotype 6 from the Netherlands 2008 and comparison to other field and vaccine strains," PLoS ONE, vol. 5, no. 4, article e10323, 2010. 
[28] P. S. Mellor and E. J. Wittmann, "Bluetongue virus in the mediterranean basin 1998-2001," Veterinary Journal, vol. 164, no. 1, pp. 20-37, 2002.

[29] C. De Liberato, G. Scavia, R. Lorenzetti et al., "Identification of Culicoides obsoletus (Diptera: Ceratopogonidae) as a vector of bluetongue virus in central Italy," Veterinary Record, vol. 156, no. 10, pp. 301-304, 2005.

[30] R. Meiswinkel, T. Baldet, R. de Deken, W. Takken, J. C. Delécolle, and P. S. Mellor, "The 2006 outbreak of bluetongue in northern Europe-The entomological perspective," Preventive Veterinary Medicine, vol. 87, no. 1-2, pp. 55-63, 2008.

[31] K. A. McColl and A. R. Gould, "Detection and characterisation of bluetongue virus using the polymerase chain reaction," Virus Research, vol. 21, no. 1, pp. 19-34, 1991.

[32] W. C. Wilson and C. C. L. Chase, "Nested and multiplex polymerase chain reactions for the identification of bluetongue virus infection in the biting midge, Culicoides variipennis," Journal of Virological Methods, vol. 45, no. 1, pp. 39-47, 1993.

[33] C. Billinis, M. Koumbati, V. Spyrou et al., "Bluetongue virus diagnosis of clinical cases by a duplex reverse transcriptionPCR: A comparison with conventional methods," Journal of Virological Methods, vol. 98, no. 1, pp. 77-89, 2001.

[34] W. C. Wilson, D. E. Stallknecht, and J. O. Mecham, "Field deployable real-time polymerase chain reaction detection of bluetongue and epizootic haemorrhagic disease viral ribonucleic acid," Veterinia Italiana, vol. 40, pp. 587-593, 2004.

[35] M. A. Jiménez-Clavero, M. Agüero, E. San Miguel et al., "High throughput detection of bluetongue virus by a new real-time fluorogenic reverse transcription-polymerase chain reaction: application on clinical samples from current Mediterranean outbreaks," Journal of Veterinary Diagnostic Investigation, vol. 18, no. 1, pp. 7-17, 2006.

[36] P. P. C. Mertens, N. S. Maan, G. Prasad et al., "Design of primers and use of RT-PCR assays for typing European bluetongue virus isolates: differentiation of field and vaccine strains," Journal of General Virology, vol. 88, no. 10, pp. 2811 2823, 2007.

[37] G. Orrù, M. L. Ferrando, M. Meloni, M. Liciardi, G. Savini, and P. De Santis, "Rapid detection and quantitation of Bluetongue virus (BTV) using a Molecular Beacon fluorescent probe assay," Journal of Virological Methods, vol. 137, no. 1, pp. 34-42, 2006.

[38] S. Anthony, H. Jones, K. E. Darpel et al., "A duplex RT-PCR assay for detection of genome segment 7 (VP7 gene) from 24 BTV serotypes," Journal of Virological Methods, vol. 141, no. 2, pp. 188-197, 2007.

[39] A. E. Shaw, P. Monaghan, H. O. Alpar et al., "Development and initial evaluation of a real-time RT-PCR assay to detect bluetongue virus genome segment 1," Journal of Virological Methods, vol. 145, no. 2, pp. 115-126, 2007.

[40] J. F. Toussaint, C. Sailleau, E. Breard, S. Zientara, and K. De Clercq, "Bluetongue virus detection by two real-time RTqPCRs targeting two different genomic segments," Journal of Virological Methods, vol. 140, no. 1-2, pp. 115-123, 2007.

[41] D. W. Verwoerd, H. Louw, and R. A. Oellermann, "Characterization of bluetongue virus ribonucleic acid," Journal of Virology, vol. 5, no. 1, pp. 1-7, 1970.

[42] N. Le Blanc, T. B. Rassmussen, J. Fernandez et al., "Development of a real-time RT-PCR assay based on primerprobe energy transfer for the detection of all serotypes of bluetongue virus," Journal Virological Methods, vol. 167, pp. 165-171, 1970.
[43] P. S. Mellor and C. Hamblin, "African horse sickness," Veterinary Research, vol. 35, no. 4, pp. 445-466, 2004.

[44] M. Rodriguez, H. Hooghuis, and M. Castano, "African horse sickness in Spain," Veterinary Microbiology, vol. 33, no. 1-4, pp. 129-142, 1992.

[45] M. Portas, F. S. Boinas, J. O. E. Sousa, and P. Rawlings, "African horse sickness in Portugal: a successful eradication programme," Epidemiology and Infection, vol. 123, no. 2, pp. 337-346, 1999.

[46] R. Meiswinkel and J. T. Paweska, "Evidence for a new field Culicoides vector of African horse sickness in South Africa," Preventive Veterinary Medicine, vol. 60, no. 3, pp. 243-253, 2003.

[47] S. Zientara, C. Sailleau, S. Moulay, E. Plateau, and C. Crucière, "Diagnosis and molecular epidemiology of the African horse sickness virus by the polymerase chain reaction and restriction patterns," Veterinary research, vol. 24, no. 5, pp. 385-395, 1993.

[48] S. Zientara, "Application of the polymerase chain reaction to the detection of African horse sickness viruses," Journal of Virological Methods, vol. 53, no. 1, pp. 47-54, 1995.

[49] S. Moulay, S. Zientara, C. Sailleau, and C. Cruciere, "Detection of African horse sickness viruses by dot-blot hybridization using a digoxigenin-labelled probe," Molecular and Cellular Probes, vol. 9, no. 4, pp. 233-237, 1995.

[50] S. Zientara, C. Sailleau, S. Moulay, and C. Cruciere, "Diagnosis of the African horse sickness virus serotype 4 by a one-tube, one manipulation RT-PCR reaction from infected organs," Journal of Virological Methods, vol. 46, no. 2, pp. 179-188, 1994.

[51] C. Sailleau, C. Hamblin, J. T. Paweska, and S. Zientara, "Identification and differentiation of the nine African horse sickness virus serotypes by RT-PCR amplification of the serotype-specific genome segment 2," Journal of General Virology, vol. 81, no. 3, pp. 831-837, 2000.

[52] I. E. Aradaib, M. E. H. Mohemmed, J. A. Sarr et al., "Short communication: a simple and rapid method for detection of African horse sickness virus serogroup in cell cultures using RT-PCR," Veterinary Research Communications, vol. 30, no. 3, pp. 319-324, 2006.

[53] M. Agüero, C. Gómez-Tejedor, M. Á. Cubillo, C. Rubio, E. Romero, and M. A. Jiménez-Clavero, "Real-time fluorogenic reverse transcription polymerase chain reaction assay for detection of African horse sickness virus," Journal of Veterinary Diagnostic Investigation, vol. 20, no. 3, pp. 325-328, 2008.

[54] J. J. O. Koekemoer, "Serotype-specific detection of African horsesickness virus by real-time PCR and the influence of genetic variations," Journal of Virological Methods, vol. 154, no. 1-2, pp. 104-110, 2008.

[55] B. Rodriguez-Sanchez, J. Fernandez-Pinero, C. Sailleau et al., "Novel gel-based and real-time PCR assays for the improved detection of African horse sickness virus," Journal of Virological Methods, vol. 151, no. 1, pp. 87-94, 2008.

[56] J. Fernandez-Pinero, P. Fernandez-Pacheco, B. Rodriguez et al., "Rapid and sensitive detection of African horse sickness virus by real-time PCR," Research in Veterinary Science, vol. 86, pp. 353-358, 2008.

[57] M. Quan, C. W. Lourens, N. J. MacLachlan, I. A. Gardner, and A. J. Guthrie, "Development and optimisation of a duplex real-time reverse transcription quantitative PCR assay targeting the VP7 and NS2 genes of African horse sickness 
virus," Journal of Virological Methods, vol. 167, no. 1, pp. 4552, 2010.

[58] I. E. Aradaib, "PCR detection of African horse sickness virus serogroup based on genome segment three sequence analysis," Journal of Virological Methods, vol. 159, no. 1, pp. $1-5,2009$.

[59] H. Yadin, J. Brenner, V. Bumbrov et al., "Epizootic haemorrhagic disease virus type 7 infection in cattle in Israel," Veterinary Record, vol. 162, no. 2, pp. 53-56, 2008.

[60] R. P. Weir, M. B. Harmsen, N. T. Hunt et al., "EHDV-1, a new Australian serotype of epizootic haemorrhagic disease virus isolated from sentinel cattle in the Northern Territory," Veterinary Microbiology, vol. 58, no. 2-4, pp. 135-143, 1997.

[61] E. Bréard, C. Sailleau, C. Hamblin, S. D. Graham, J. M. Gourreau, and S. Zientara, "Outbreak of epizootic haemorrhagic disease on the island of Ré union," Veterinary Record, vol. 155, no. 14, pp. 422-423, 2004.

[62] E. M. Temizel, K. Yesilbag, C. Batten et al., "Epizootic hemorrhagic disease in cattle, Western Turkey," Emerging Infectious Diseases, vol. 15, no. 2, pp. 317-319, 2009.

[63] I. E. Aradaib, W. C. Wilson, I. W. Cheney, J. E. Pearson, and B. I. Osburn, "Application of PCR for specific identification of epizootic hemorrhagic disease virus serotype 2," Journal of Veterinary Diagnostic Investigation, vol. 7, no. 3, pp. 388-392, 1995.

[64] M. J. Harding, I. Prud'homme, J. Rola, and G. C. Dulac, "Development of PCR-based tests for the identification of North American isolates of epizootic haemorrhagic disease virus," Canadian Journal of Veterinary Research, vol. 60, no. 1, pp. 59-64, 1996.

[65] I. E. Aradaib, W. C. Wilson, C. E. Schore et al., "PCR detection of North American and Central African isolates of epizootic hemorrhagic disease virus (EHDV) based on genome segment 10 of EHDV serotype 1," Journal of Clinical Microbiology, vol. 36, no. 9, pp. 2604-2608, 1998.

[66] I. E. Aradaib, W. L. Smith, B. I. Osburn, and J. S. Cullor, "A multiplex PCR for simultaneous detection and differentiation of North American serotypes of bluetongue and epizootic hemorrhagic disease viruses," Comparative Immunology, Microbiology and Infectious Diseases, vol. 26, no. 2, pp. 77-87, 2003.

[67] N. S. Maan, S. Maan, K. Nomikou et al., "RT-PCR assays for seven serotypes of epizootic haemorrhagic disease virus \& their use to type strains from the mediterranean region and North America," PLoS ONE, vol. 5, no. 9, article e12782, pp. $1-13,2010$.

[68] W. C. Wilson, E. S. O’Hearn, C. Tellgren-Roth, D. E. Stallknecht, D. G. Mead, and J. O. Mecham, "Detection of all eight serotypes of Epizootic hemorrhagic disease virus by real-time reverse transcription polymerase chain reaction," Journal of Veterinary Diagnostic Investigation, vol. 21, no. 2, pp. 220-225, 2009.

[69] M. F. Uren, "Bovine ephemeral disease," Australian Veterinary Journal, vol. 66, pp. 233-236, 1989.

[70] S. Nandi and B. S. Negi, "Bovine ephemeral fever: a review," Comparative Immunology, Microbiology and Infectious Diseases, vol. 22, no. 2, pp. 81-91, 1999.

[71] P. J. Walker, "Bovine ephemeral fever in Australia and the world," Current Topics in Microbiology and Immunology, vol. 292, pp. 57-80, 2005.

[72] E. M. E. Abu Elzein, A. A. Gameel, A. I. Al Afaleq, O. Al Gundi, and A. Bukhari, "Bovine ephemeral fever in Saudi Arabia," Veterinary Record, vol. 140, no. 24, pp. 630-631, 1997.
[73] I. Yeruham, M. Van Ham, Y. Stram et al., "Epidemiological investigation of bovine ephemeral fever outbreaks in Israel," Veterinary Medicine International, vol. 2010, Article ID 290541, 5 pages, 2010.

[74] F. G. Davies and A. R. Walker, "The isolation of ephemeral fever virus from cattle and Culicoides midges in Kenya," Veterinary Record, vol. 95, no. 3, pp. 63-64, 1974.

[75] T. D. St George, H. A. Standfast, and A. L. Dyce, "Letter: the isolation of ephemeral fever virus from mosquitoes in Australia," Australian Veterinary Journal, vol. 52, no. 5, p. 242, 1976.

[76] Y. Stram, L. Kuznetzova, A. Levin, H. Yadin, and M. Rubinstein-Giuni, "A real-time RT-quantative(q)PCR for the detection of bovine ephemeral fever virus," Journal of Virological Methods, vol. 130, no. 1-2, pp. 1-6, 2005.

[77] F. Zheng, G. Lin, J. Zhou et al., "A reverse-transcription, loop-mediated isothermal amplification assay for detection of bovine ephemeral fever virus in the blood of infected cattle," Journal of Virological Methods, vol. 171, no. 1, pp. 306309, 2011.

[78] R. Kono, M. Hirata, M. Kaji et al., "Bovine epizootic encephalomyelitis caused by Akabane virus in southern Japan," BMC Veterinary Research, vol. 4, article 20, 2008.

[79] W. P. Taylor and P. S. Mellor, "The distribution of Akabane virus in the Middle East," Epidemiology and Infection, vol. 113, no. 1, pp. 175-185, 1994.

[80] S. Ohashi, K. Yoshida, T. Yanase, T. Kato, and T. Tsuda, "Simultaneous detection of bovine arboviruses using singletube multiplex reverse transcription-polymerase chain reaction," Journal of Virological Methods, vol. 120, no. 1, pp. 7985, 2004.

[81] Y. Stram, L. Kuznetzova, M. Guini et al., "Detection and quantitation of Akabane and Aino viruses by multiplex real-time reverse-transcriptase PCR," Journal of Virological Methods, vol. 116, no. 2, pp. 147-154, 2004.

[82] P. G. Howell, D. Groenewald, C. W. Visage, A. M. Bosman, J. A. W. Coetzer, and A. J. Guthrie, "The classification of seven serotypes of equine encephalosis virus and the prevalence of homologous antibody in horses in South Africa," Onderstepoort Journal of Veterinary Research, vol. 69, no. 1, pp. 79-93, 2002.

[83] Z. Mildenberg, D. Westcott, M. Bellaiche, A. Dastjerdi, F. Steinbach, and T. Drew, "Equine encephalosis virus in Israel: rapid communication," Transboundary and Emerging Diseases, vol. 56, no. 8, p. 291, 2009.

[84] J. T. Paweska and G. J. Venter, "Vector competence of Culicoides species and the seroprevalence of homologous neutralizing antibody in horses for six serotypes of equine encephalosis virus (EEV) in South Africa," Medical and Veterinary Entomology, vol. 18, no. 4, pp. 398-407, 2004.

[85] L. L. Rodríguez, "Emergence and re-emergence of vesicular stomatitis in the United States," Virus Research, vol. 85, no. 2, pp. 211-219, 2002.

[86] K. Hole, A. Clavijo, and L. A. Pineda, "Detection and serotype-specific differentiation of vesicular stomatitis virus using a multiplex, real-time, reverse transcription-polymerase chain reaction assay," Journal of Veterinary Diagnostic Investigation, vol. 18, no. 2, pp. 139-146, 2006.

[87] W. C. Wilson, G. J. Letchworth, C. Jimenez et al., "Field evaluation of a multiplex real-time reverse transcription polymerase chain reaction assay for detection of Vesicular stomatitis virus," Journal of Veterinary Diagnostic Investigation, vol. 21, no. 2, pp. 179-186, 2009. 
[88] S. C. Weaver, A. M. Powers, A. C. Brault, and A. D. T. Barrett, "Molecular epidemiological studies of veterinary arboviral encephalitides," Veterinary Journal, vol. 157, no. 2, pp. 123 138, 1999.

[89] A. J. Lambert, D. A. Martin, and R. S. Lanciotti, "Detection of North American eastern and western equine encephalitis viruses by nucleic acid amplification assays," Journal of Clinical Microbiology, vol. 41, no. 1, pp. 379-385, 2003.

[90] M. W. Eshoo, C. A. Whitehouse, S. T. Zoll et al., "Direct broad-range detection of alphaviruses in mosquito extracts," Virology, vol. 368, no. 2, pp. 286-295, 2007.

[91] I. Takashima, T. Watanabe, N. Ouchi, and N. Hashimoto, "Ecological studies of Japanese encephalitis virus in Hokkaido: interepidemic outbreaks of swine abortion and evidence for the virus to overwinter locally," American Journal of Tropical Medicine and Hygiene, vol. 38, no. 2, pp. 420-427, 1988.

[92] E. Gould and T. Solomon, "Pathogenic flaviviruses," The Lancet, vol. 371, no. 9611, pp. 500-509, 2008.

[93] L. Rosen, "The natural history of Japanese encephalitis virus," Annual Review of Microbiology, vol. 40, pp. 395-414, 1986.

[94] T. Solomon, H. Ni, D. W. C. Beasley, M. Ekkelenkamp, M. J. Cardosa, and A. D. T. Barrett, "Origin and evolution of Japanese encephalitis virus in Southeast Asia," Journal of Virology, vol. 77, no. 5, pp. 3091-3098, 2003.

[95] T. E. Erlanger, S. Weiss, J. Keiser, J. Utzinger, and K. Wiedenmayer, "Past, present, and future of Japanese encephalitis," Emerging Infectious Diseases, vol. 15, no. 1, pp. 1-7, 2009.

[96] D. K. Yang, C. H. Kweon, B. H. Kim et al., “TaqMan reverse transcription polymerase chain reaction for the detection of Japanese encephalitis virus," Journal of Veterinary Science, vol. 5, no. 4, pp. 345-351, 2004.

[97] D. Y. Chao, B. S. Davis, and G. J. J. Chang, "Development of multiplex real-time reverse transcriptase PCR assays for detecting eight medically important flaviviruses in mosquitoes," Journal of Clinical Microbiology, vol. 45, no. 2, pp. 584-589, 2007.

[98] M. M. Parida, S. R. Santhosh, P. K. Dash et al., "Development and evaluation of reverse transcription-loop-mediated isothermal amplification assay for rapid and real-time detection of Japanese encephalitis virus," Journal of Clinical Microbiology, vol. 44, no. 11, pp. 4172-4178, 2006.

[99] H. Toriniwa and T. Komiya, "Rapid detection and quantification of Japanese encephalitis virus by real-time reverse transcription loop-mediated isothermal amplification," Microbiology and Immunology, vol. 50, no. 5, pp. 379-387, 2006.

[100] G. H. Gerdes, "Rift Valley fever," Revue Science and Technology Office International Epizooties, vol. 23, pp. 613-623, 2004.

[101] B. H. Bird, T. G. Ksiazek, S. T. Nichol, and N. J. MacLachlan, "Rift Valley fever virus," Journal of the American Veterinary Medical Association, vol. 234, no. 7, pp. 883-893, 2009.

[102] S. F. Fagbo, "The evolving transmission pattern of Rift Valley fever in the Arabian Peninsula," Annals of the New York Academy of Sciences, vol. 969, pp. 201-204, 2002.

[103] S. Garcia, J. M. Crance, A. Billecocq et al., "Quantitative real-time PCR detection of Rift Valley fever virus and its application to evaluation of antiviral compounds," Journal of Clinical Microbiology, vol. 39, no. 12, pp. 4456-4461, 2001.

[104] C. Drosten, S. Göttig, S. Schilling et al., "Rapid detection and quantification of RNA of Ebola and Marburg viruses, Lassa virus, Crimean-Congo hemorrhagic fever virus, Rift Valley fever virus, dengue virus, and yellow fever virus by real-time reverse transcription-PCR," Journal of Clinical Microbiology, vol. 40, no. 7, pp. 2323-2330, 2002.
[105] A. A. Sall, E. A. Macondo, O. K. Sène et al., "Use of reverse transcriptase PCR in early diagnosis of Rift Valley fever," Clinical and Diagnostic Laboratory Immunology, vol. 9, no. 3, pp. 713-715, 2002.

[106] M. Weidmann, M. P. Sanchez-Seco, A. A. Sall et al., "Rapid detection of important human pathogenic Phleboviruses," Journal of Clinical Virology, vol. 41, no. 2, pp. 138-142, 2008.

[107] C. N. Peyrefitte, L. Boubis, D. Coudrier et al., "Real-time reverse-transcription loop-mediated isothermal amplification for rapid detection of Rift Valley fever virus," Journal of Clinical Microbiology, vol. 46, no. 11, pp. 3653-3659, 2008.

[108] C. A. Le Roux, T. Kubo, A. A. Grobbelaar et al., "Development and evaluation of a real-time reverse transcriptionloop- mediated isothermal amplification assay for rapid detection of rift valley fever virus in clinical specimens," Journal of Clinical Microbiology, vol. 47, no. 3, pp. 645-651, 2009.

[109] K. E. Weiss, D. A. Haig, and R. A. Alexander, "Wesselsbron virus-a virus not previously describes, associated with abortion in domestic animals," Onderstepoort Journal of Veterinary Research, vol. 27, pp. 183-195, 1956.

[110] A. H. Fagbami, "Susceptibility of west African dwarf sheep to the indigenous Wesselsbron virus," British Veterinary Journal, vol. 136, no. 1, pp. 57-62, 1980.

[111] B. J. Barnard and S. F. Voges, "Flaviviruses in South Africa: pathogenicity for sheep," Onderstepoort Journal of Veterinary Research, vol. 53, no. 4, pp. 235-238, 1986.

[112] S. S. Baba, A. H. Fagbami, C. K. Ojeh, O. D. Olaleye, and S. A. Omilabu, "Wesselsbron virus antibody in domestic animals in Nigeria: retrospective and prospective studies," The New Microbiologica, vol. 18, no. 2, pp. 151-162, 1995.

[113] M. Diallo, P. Nabeth, K. Ba et al., "Mosquito vectors of the 1998-1999 outbreak of Rift Valley Fever and other arboviruses (Bagaza, Sanar, Wesselsbron and West Nile) in Mauritania and Senegal," Medical and Veterinary Entomology, vol. 19, no. 2, pp. 119-126, 2005.

[114] G. Moureau, S. Temmam, J. P. Gonzalez, R. N. Charrel, G. Grard, and X. De Lamballerie, "A real-time RT-PCR method for the universal detection and identification of flaviviruses," Vector-Borne and Zoonotic Diseases, vol. 7, no. 4, pp. 467-477, 2007.

[115] J. Castillo-Olivares and J. Wood, "West Nile virus infection of horses," Veterinary Research, vol. 35, no. 4, pp. 467-483, 2004.

[116] H. G. Zeller and I. Schuffenecker, "West Nile virus: An overview of its spread in Europe and the Mediterranean basin in contrast to its spread in the Americas," European Journal of Clinical Microbiology and Infectious Diseases, vol. 23, no. 3, pp. 147-156, 2004.

[117] L. D. Kramer, L. M. Styer, and G. D. Ebel, "A global perspective on the epidemiology of West Nile virus," Annual Review of Entomology, vol. 53, pp. 61-81, 2008.

[118] K. O. Murray, C. Walker, and E. Gould, "The virology, epidemiology, and clinical impact of West nile virus: a decade of advancements in research since its introduction into the Western Hemisphere," Epidemiology and Infection, vol. 139, pp. 807-817, 2011.

[119] S. Higgs, K. Snow, and E. A. Gould, "The potential for West Nile virus to establish outside of its narural range: a consideration of potential mosquito vectors in the United Kingdom," Transactions of the Royal Society of Tropical Medicine and Hygiene, vol. 98, no. 2, pp. 82-87, 2004.

[120] P. Y. Shi and L. D. Kramer, "Molecular detection of West Nile virus RNA," Expert Review of Molecular Diagnostics, vol. 3, no. 3, pp. 357-366, 2003. 
[121] R. S. Lanciotti, A. J. Kerst, R. S. Nasci et al., "Rapid detection of West Nile virus from human clinical specimens, fieldcollected moquitoes, and avian samples by a TaqMan reverse transcriptase-PCR assay," Journal of Clinical Microbiology, vol. 38, pp. 4066-4071, 2001.

[122] J. Dyer, D. M. Chisenhall, and C. N. Mores, "A multiplexed TaqMan assay for the detection of arthropod-borne flaviviruses," Journal of Virological Methods, vol. 145, no. 1, pp. 9-13, 2007.

[123] F. Naze, K. Le Roux, I. Schuffenecker et al., "Simultaneous detection and quantitation of Chikungunya, Dengue and West Nile viruses by multiplex RT-PCR assays and Dengue virus typing using High Resolution Melting," Journal of Virological Methods, vol. 162, no. 1-2, pp. 1-7, 2009.

[124] D. Zaayman, S. Human, and M. Venter, "A highly sensitive method for the detection and genotyping of West Nile virus by real-time PCR," Journal of Virological Methods, vol. 157, no. 2, pp. 155-160, 2009.

[125] M. Parida, G. Posadas, S. Inoue, F. Hasebe, and K. Morita, "Real-time reverse transcription loop-mediated isothermal amplification for rapid detection of west nile virus," Journal of Clinical Microbiology, vol. 42, no. 1, pp. 257-263, 2004.

[126] N. Perera, H. Aonuma, A. Yoshimura et al., "Rapid identification of virus-carrying mosquitoes using reverse transcription-loop-mediated isothermal amplification," Journal of Virological Methods, vol. 156, no. 1-2, pp. 32-36, 2009.

[127] M. L. Penrith and W. Vosloo, "Review of African swine fever: transmission, spread and control," Journal of the South African Veterinary Association, vol. 80, no. 2, pp. 58-62, 2009.

[128] B. A. Lubisi, A. D. S. Bastos, R. M. Dwarka, and W. Vosloo, "Molecular epidemiology of African swine fever in East Africa," Archives of Virology, vol. 150, no. 12, pp. 2439-2452, 2005.

[129] P. J. Wilkinson, R. G. Pegram, B. D. Perry, J. Lemche, and H. F. Schels, "The distribution of African swine fever virus isolated from Ornithodoros moubata in Zambia," Epidemiology and Infection, vol. 101, no. 3, pp. 547-564, 1988.

[130] S. Bech-Nielsen, J. Fernandez, F. Martinez-Pereda, J. Espinosa, Q. Perez Bonilla, and J. M. Sanchez-Vizcaino, "A case study of an outbreak of African swine fever in Spain," British Veterinary Journal, vol. 151, no. 2, pp. 203-214, 1995.

[131] J. Ravaomanana, V. Michaud, F. Jori et al., "First detection of African swine fever virus in Ornithidorus porcinus in Madagascar and new insights into tick distribution and taxonomy," Parasitology Vectors, vol. 3, p. 115, 2010.

[132] R. J. Rowlands, V. Michaud, L. Heath et al., "African swine fever virus isolate, Georgia, 2007," Emerging Infectious Diseases, vol. 14, no. 12, pp. 1870-1874, 2008.

[133] P. Rahimi, A. Sohrabi, J. Ashrafihelan et al., "Emergence of African swine fever virus, northwestern Iran," Emerging Infectious Diseases, vol. 16, no. 12, pp. 1946-1948, 2010.

[134] B. A. Lubisi, R. M. Dwarka, D. Meenowa, and R. Jaumally, "An Investigation into the first outbreak of african swine fever in the republic of mauritius," Transboundary and Emerging Diseases, vol. 56, no. 5, pp. 178-188, 2009.

[135] M. Labuda and P. A. Nuttall, "Tick-borne viruses," Parasitology, vol. 129, pp. S221-S245, 2004.

[136] D. P. King, S. M. Reid, G. H. Hutchings et al., "Development of a TaqMan PCR assay with internal amplification control for the detection of African swine fever virus," Journal of Virological Methods, vol. 107, no. 1, pp. 53-61, 2003.

[137] J. McKillen, B. Hjertner, A. Millar et al., "Molecular beacon real-time PCR detection of swine viruses," Journal of Virological Methods, vol. 140, no. 1-2, pp. 155-165, 2007.
[138] J. McKillen, M. McMenamy, B. Hjertner et al., "Sensitive detection of African swine fever virus using real-time PCR with a 5' conjugated minor groove binder probe," Journal of Virological Methods, vol. 168, no. 1-2, pp. 141-146, 2010.

[139] H. E. James, K. Ebert, R. McGonigle et al., "Detection of African swine fever virus by loop-mediated isothermal amplification," Journal of Virological Methods, vol. 164, no. 1-2, pp. 68-74, 2010.

[140] B. Ronish, M. Hakhverdyan, K. Stahl et al., "Design and verification of a highly reliable Linear-After-The-Exponential PCR (LATE-PCR) assay for the detection of African swine fever," Journal of Virological Methods, vol. 172, pp. 8-15, 2011.

[141] O. Ergonul, "Crimean-Congo haemorrhagic fever," Lancet Infectious Diseases, vol. 6, no. 4, pp. 203-214, 2006.

[142] R. Swanepoel, A. J. Shepherd, P. A. Leman et al., "Epidemiologic and clinical features of Crimean-Congo hemorrhagic fever in southern Africa," American Journal of Tropical Medicine and Hygiene, vol. 36, no. 1, pp. 120-132, 1987.

[143] A. Zavitsanou, F. Babatsikou, and C. Koutis, "Crimean Congo hemorrhagic fever: an emerging tick-borne disease," Health Science Journal, vol. 3, no. 1, pp. 10-18, 2009.

[144] M. I. Burney, A. Ghafoor, M. Saleen et al., "Nosocomial outbreak of viral hemorrhagic fever caused by Crimean hemorrhagic fever-Congo virus in Pakistan, January 1976," American Journal of Tropical Medicine and Hygiene, vol. 29, no. 5, pp. 941-947, 1980.

[145] A. S. Khan, G. O. Maupin, P. E. Rollin et al., "An outbreak of Crimean-Congo hemorrhagic fever in the United Arab Emirates, 1994-1995," American Journal of Tropical Medicine and Hygiene, vol. 57, no. 5, pp. 519-525, 1997.

[146] Y. Gurbuz, I. Sencan, B. Orturk, and E. Tutuncu, "A case of nosocomial transmission of Crimean-Congo hemorrhagic fever from patient to patient," International Journal of Infectious Diseases, vol. 13, pp. e105-e107, 2009.

[147] I. E. Aradaib, B. R. Erickson, M. E. Mustafa et al., "Nosocomial outbreak of crimean-congo hemorrhagic fever, Sudan," Emerging Infectious Diseases, vol. 16, no. 5, pp. 837-839, 2010.

[148] H. R. Naderi, M. R. Sarvghad, A. Bojdy et al., "Nosocomial outbreak of Crimean-Congo heamorrhagic fever," Epidemiology and Infection, vol. 139, pp. 862-866, 2010.

[149] G. R. Yilmaz, T. Buzgan, H. Irmak et al., "The epidemiology of Crimean-Congo hemorrhagic fever in Turkey, 20022007," International Journal of Infectious Diseases, vol. 13, no. 3, pp. 380-386, 2009.

[150] O. M. E. El-Azazy and E. M. Scrimgeour, "Crimean-Congo haemorrhagic fever virus infection in the Western Province of Saudi Arabia," Transactions of the Royal Society of Tropical Medicine and Hygiene, vol. 91, no. 3, pp. 275-278, 1997.

[151] H. C. Maltezou, A. Papa, S. Tsiodras, V. Dalla, E. Maltezos, and A. Antoniadis, "Crimean-Congo hemorrhagic fever in Greece: a public health perspective," International Journal of Infectious Diseases, vol. 13, no. 6, pp. 713-716, 2009.

[152] R. M. Vorou, "Crimean-Congo hemorrhagic fever in southeastern Europe," International Journal of Infectious Diseases, vol. 13, no. 6, pp. 659-662, 2009.

[153] A. Papa, V. Dalla, E. Papadimitriou, G. N. Kartalis, and A. Antoniadis, "Emergence of Crimean-Congo haemorrhagic fever in Greece," Clinical Microbiology and Infection, vol. 16, no. 7, pp. 843-847, 2010.

[154] H. Hoogstraal, "The epidemiology of tick-borne CrimeanCongo hemorrhagic fever in Asia, Europe, and Africa," Journal of Medical Entomology, vol. 15, no. 4, pp. 307-417, 1979. 
[155] T. F. Schwarz, H. Nsanze, M. Longson et al., "Polymerase chain reaction for diagnosis and identification of distinct variants of Crimean-Congo hemorrhagic fever virus in the United Arab Emirates," American Journal of Tropical Medicine and Hygiene, vol. 55, no. 2, pp. 190-196, 1996.

[156] C. Drosten, B. M. Kummerer, H. Schmitz, and S. Gunther, "Molecular diagnostics of viral haemorrhagic fevers," Antiviral Research, vol. 57, pp. 61-87, 2003.

[157] M. Yapar, H. Aydogan, A. Pahsa et al., "Rapid and quantitative detection of Crimean-Congo hemorrhagic fever virus by one-step real-time reverse transcriptase-PCR," Japanese Journal of Infectious Diseases, vol. 58, no. 6, pp. 358-362, 2005.

[158] D. Duh, A. Saksida, M. Petrovec, I. Dedushaj, and T. AvšičŽUpanc, "Novel one-step real-time RT-PCR assay for rapid and specific diagnosis of Crimean-Congo hemorrhagic fever encountered in the Balkans," Journal of Virological Methods, vol. 133, no. 2, pp. 175-179, 2006.

[159] F. G. Davies, "Nairobi sheep disease," Parassitologia, vol. 39, no. 2, pp. 95-98, 1997.

[160] G. M. Mugera and S. Chema, "Nairobi sheep disease: a study of its pathogenesis in sheep, goats and suckling mice," Bulletin of Epizootic Diseases of Africa, vol. 15, no. 4, pp. 337354, 1967.

[161] B. I. Marczinke and S. T. Nichol, "Nairobi sheep disease virus, an important tick-borne pathogen of sheep and goats in Africa, is also present in Asia," Virology, vol. 303, no. 1, pp. 146-151, 2002.

[162] A. B. Sudeep, R. S. Jadi, and A. C. Mishra, "Ganjam virus," Indian Journal of Medical Research, vol. 130, no. 5, pp. 514519, 2009.

[163] R. E. Montgomery, "On a tick borne gastro-enteritis of sheep and goats occurring in East Africa," Journal of Comparative Pathology, vol. 30, pp. 28-57, 1917.

[164] F. G. Davies, "Nairobi sheep disease in Kenya. The isolation of virus from sheep and goats, ticks and possible maintenance hosts," Journal of Hygiene, vol. 81, no. 2, pp. 259-265, 1978.

[165] C. Terpstra, "Nairobi sheep disease," in Infectious Diseases of Livestock with Special Reference to Southern Africa, J. A. W. Coetzer, G. R. Thompson, and R. C. Tustin, Eds., pp. 718722, Oxford University Press, Cape Town, South Africa, 1993.

[166] J. E. Honig, J. C. Osborne, and S. T. Nichol, "The high genetic variation of viruses of the genus Nairovirus reflects the diversity of their predominant tick hosts," Virology, vol. 318, no. 1, pp. 10-16, 2004.

[167] R. Sang, C. Onyango, J. Gachoya et al., “Tickborne arbovirus surveillance in market livestock, Nairobi, Kenya," Emerging Infectious Diseases, vol. 12, no. 7, pp. 1074-1080, 2006.

[168] J. Jüss, "Tick-borne encephalitis in Europe and beyond-the epidemiological situation as of 2007," Eurosurveillance, no. 13, p. 18916, 2008.

[169] T. S. Gritsun, V. A. Lashkevich, and E. A. Gould, "Tick-borne encephalitis," Antiviral Research, vol. 57, no. 1-2, pp. 129146, 2003.

[170] C. P. MacKenzie, N. D. Lewis, S. T. Smith, and R. W. Muir, "Louping-ill in a working collie," Veterinary Record, vol. 92, no. 14, pp. 354-356, 1973.

[171] H. W. Reid, R. M. Barlow, and J. B. Boyce, "Isolation of louping-ill virus from a roe deer (Caperolus cepreolus)," Veterinary Record, vol. 98, p. 116, 1976.

[172] H. W. Reid, R. M. Barlow, and I. Pow, "Isolation of loupingill virus from red deer (Cervus elaphus)," Veterinary Record, vol. 102, no. 21, pp. 463-464, 1978.
[173] C. Macaldowie, I. A. P. Patterson, P. F. Nettleton, H. Low, and D. Buxton, "Louping ill in llamas (Lama glama) in the Hebrides," Veterinary Record, vol. 156, no. 13, pp. 420-421, 2005.

[174] M. S. Marin, J. McKenzie, G. F. Gao, H. W. Reid, A. Antoniadis, and E. A. Gould, "The virus causing encephalomyelitis in sheep in Spain: a new member of the tick-borne encephalitis group," Research in Veterinary Science, vol. 58, no. 1, pp. 11-13, 1995.

[175] K. L. Mansfield, N. Johnson, L. P. Phipps, J. R. Stephenson, A. R. Fooks, and T. Solomon, "Tick-borne encephalitis virus-a review of an emerging zoonosis," Journal of General Virology, vol. 90, no. 8, pp. 1781-1794, 2009.

[176] K. McGuire, E. C. Holmes, G. F. Gao, H. W. Reid, and E. A. Gould, "Tracing the origins of louping ill virus by molecular phylogenetic analysis," Journal of General Virology, vol. 79, no. 5, pp. 981-988, 1998.

[177] L. Gonzalez, H. W. Reid, I. Pow, and J. S. Gilmour, "A disease resembling louping-ill in sheep in the Basque region of Spain," Veterinary Record, vol. 121, no. 1, pp. 12-13, 1987.

[178] O. Papadopoulos, E. Paschaleri-Papadopoulou, N. Deligaris, and G. Doukas, "Isolation of tick-borne encephalitis virus from a flock of goats with abortions and fatal disease (preliminary report)," Veterinary News Greece, vol. 3, pp. 112114, 1971.

[179] V. Pavlidou, S. Gerou, E. Diza, A. Antoniadis, and A. Papa, "Genetic study of the distribution of greek goat encephalitis virus in Greece," Vector-Borne and Zoonotic Diseases, vol. 8, no. 3, pp. 351-354, 2008.

[180] W. J. Hartley, W. B. Martin, F. Hakiolu, and S. T. E. Chifney, "A viral encephalitis of sheep in Turkey," Pendik Institute Journal, vol. 2, pp. 89-100, 1969.

[181] G. F. Gao, W. R. Jiang, M. H. Hussain et al., "Sequencing and antigenic studies of a Norwegian virus isolated from encephalomyelitic sheep confirm the existence of louping ill virus outside Great Britain and Ireland," Journal of General Virology, vol. 74, no. 1, pp. 109-114, 1993.

[182] J. E. Whitby, S. N. Whitby, A. D. Jennings, J. R. Stephenson, and A. D. T. Barrett, "Nucleotide sequence of the envelope protein of a Turkish isolate of tick-borne encephalitis (TBE) virus is distinct from other viruses of the TBE virus complex," Journal of General Virology, vol. 74, no. 5, pp. 921-924, 1993.

[183] P. Hudson, E. Gould, K. Laurenson et al., "The epidemiology of louping-ill, a tick borne infection of red grouse (Lagopus lagopus scoticus)," Parassitologia, vol. 39, no. 4, pp. 319-323, 1997.

[184] M. W. Gaunt, L. D. Jones, K. Laurenson, P. J. Hudson, H. W. Reid, and E. A. Gould, "Definitive identification of louping ill virus by RT-PCR and sequencing in field populations of Ixodes ricinus on the Lochindorb estate," Archives of Virology, vol. 142, no. 6, pp. 1181-1191, 1997.

[185] L. Marriott, K. Willoughby, F. Chianini et al., "Detection of Louping ill virus in clinical specimens from mammals and birds using TaqMan RT-PCR," Journal of Virological Methods, vol. 137, no. 1, pp. 21-28, 2006.

[186] N. Johnson, P. R. Wakeley, K. L. Mansfield et al., "Assessment of a novel real-time pan-flavivirus RT-polymerase chain reaction," Vector-Borne and Zoonotic Diseases, vol. 10, no. 7, pp. 665-671, 2010.

[187] K. Achazi, A. Nitsche, P. Patel, A. Radonić, O. D. Mantke, and M. Niedrig, "Detection and differentiation of tickborne encephalitis virus subtypes by a reverse transcription quantitative real-time PCR and pyrosequencing," Journal of Virological Methods, vol. 171, no. 1, pp. 34-39, 2011. 
[188] G. Palacios, C. Cowled, A. V. Bussetti et al., "Rapid molecular strategy for orbivirus detection and characterization," Journal of Clinical Microbiology, vol. 49, pp. 2314-2317, 2011.

[189] G. Palacios, P. L. Quan, O. J. Jabado et al., "Panmicrobial oligonucleotide array for diagnosis of infectious diseases," Emerging Infectious Diseases, vol. 13, no. 1, pp. 73-81, 2007.

[190] C. F. Wright, M. J. Morelli, G. Thébaud et al., "Beyond the consensus: dissecting within-host viral population diversity of foot-and-mouth disease virus by using next-generation genome sequencing," Journal of Virology, vol. 85, pp. 2266$2275,2011$. 

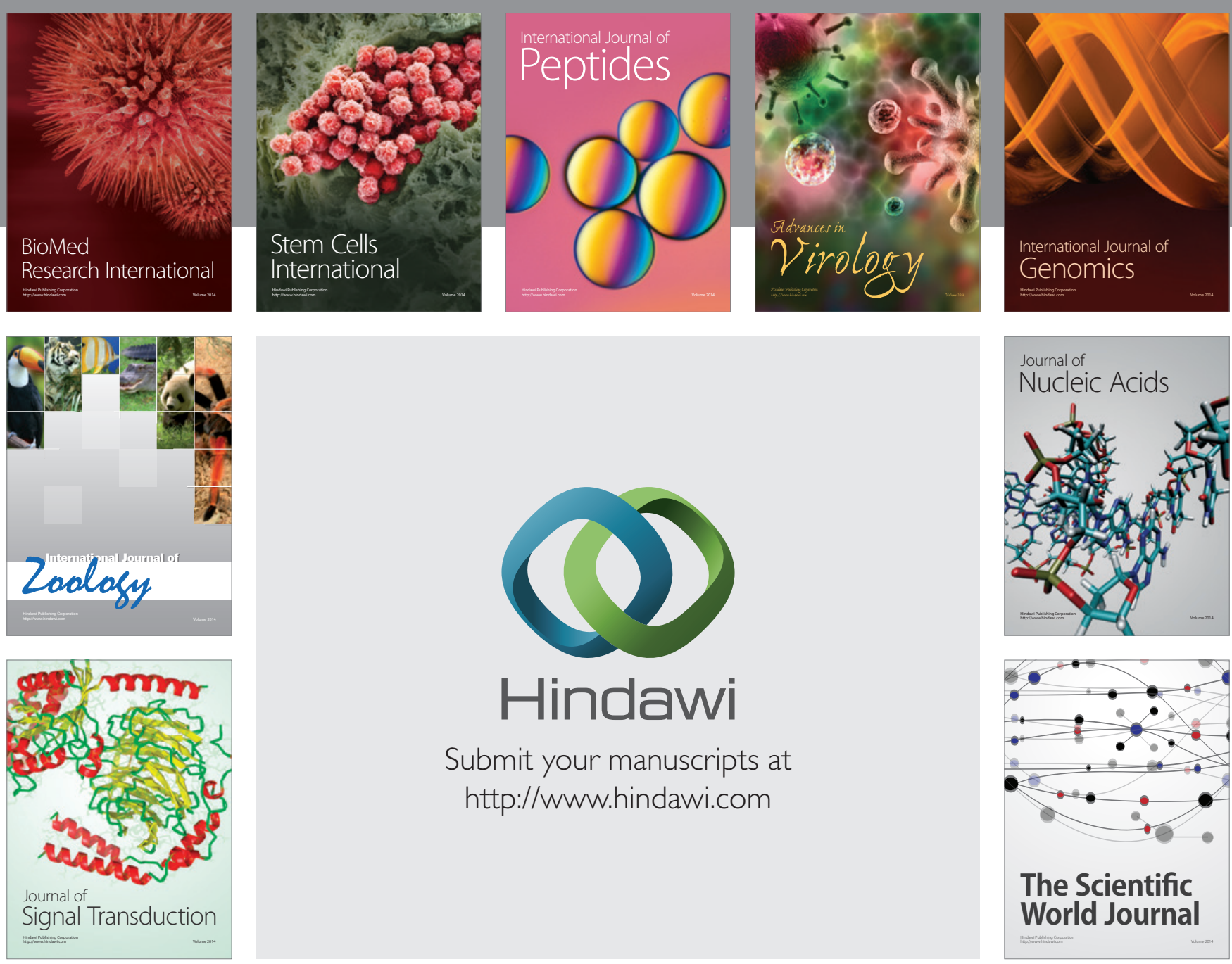

Submit your manuscripts at

http://www.hindawi.com
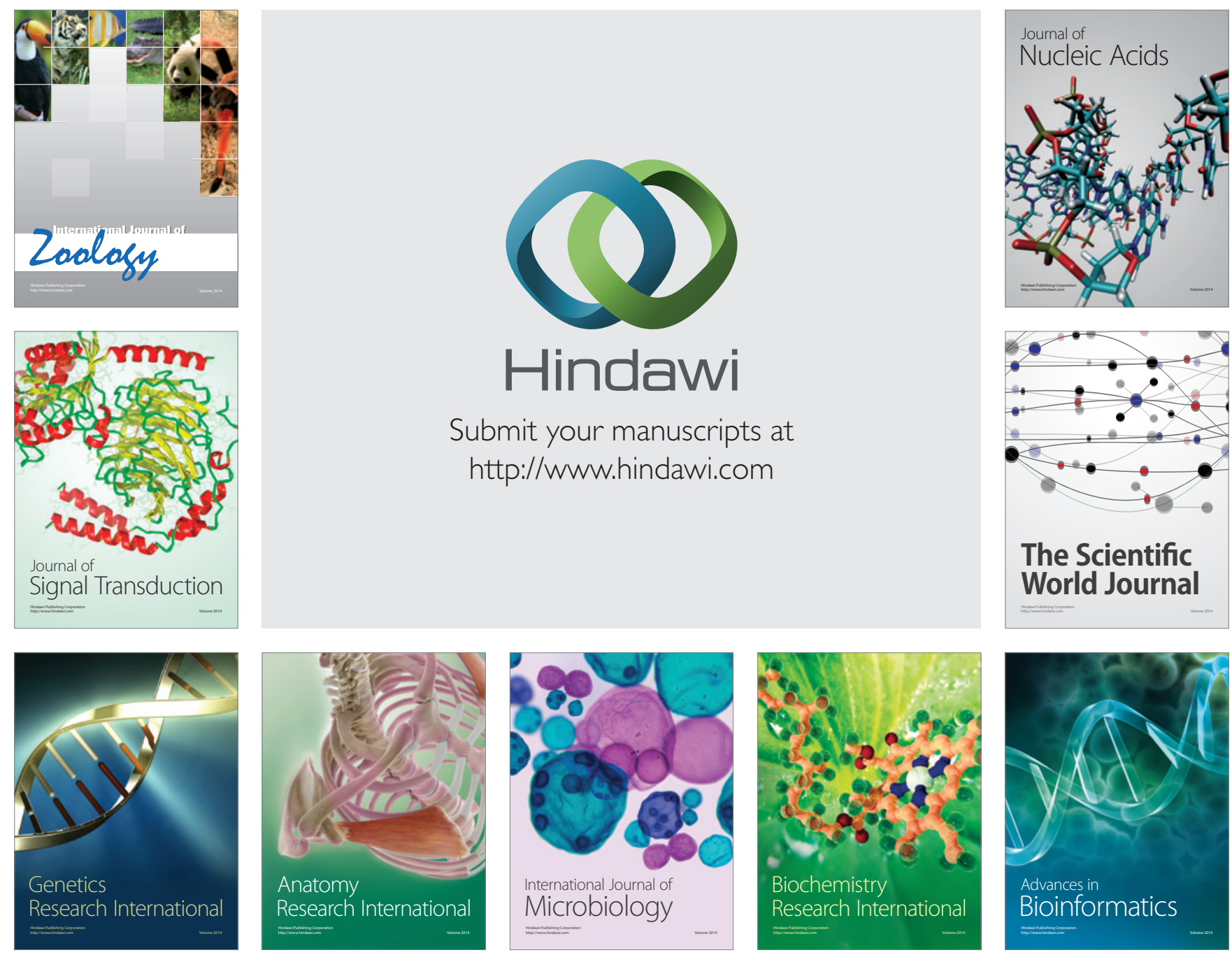

The Scientific World Journal
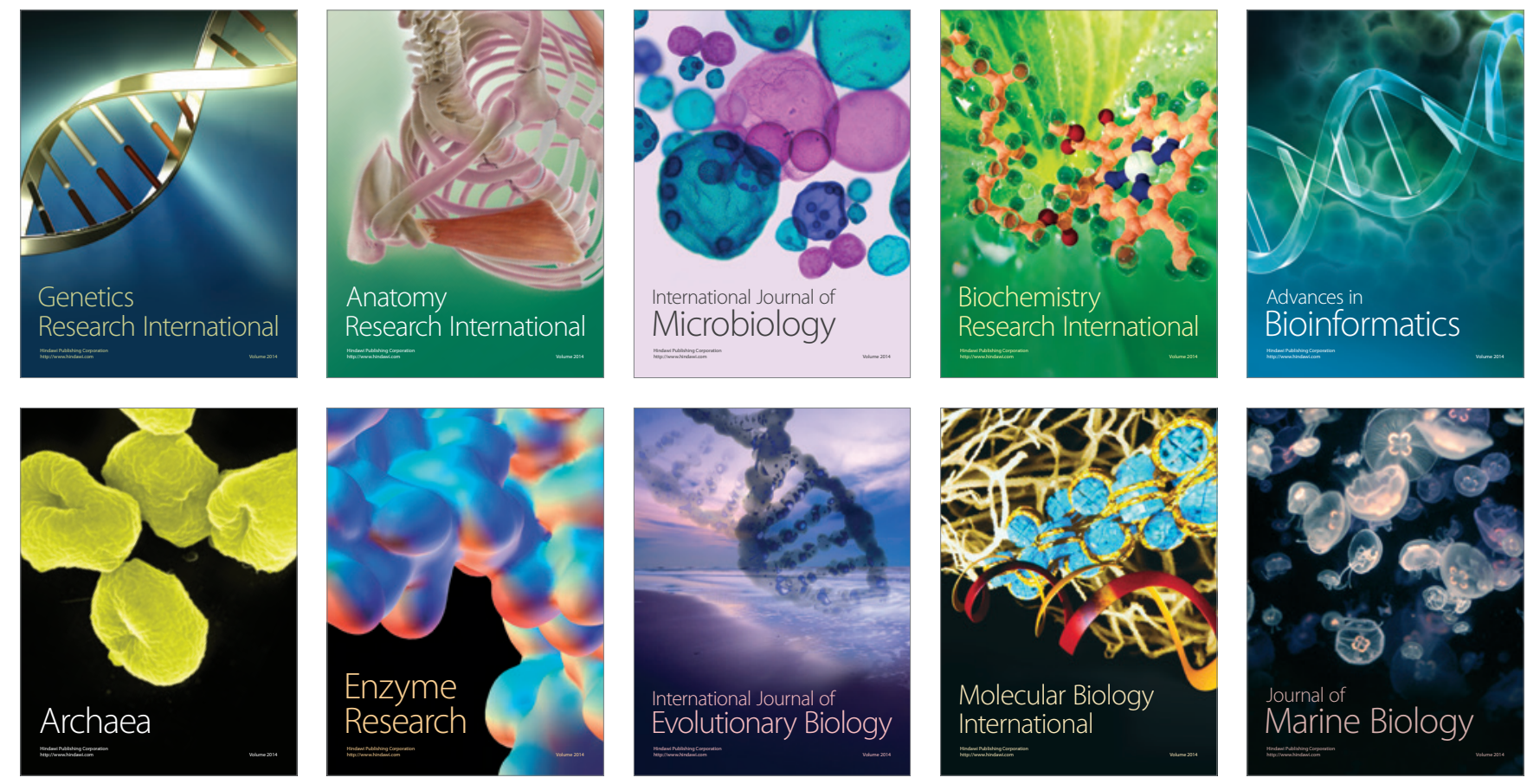